\title{
Synthesis of C8-Arylamine-Modified 2'-Deoxyadenosine Phosphoramidites and their Site-Specific Incorporation into Oligonucleotides
}

\author{
Zita Szombati, ${ }^{[a]}$ Sabrina Baerns, ${ }^{[b]}$ Andreas Marx, ${ }^{[b]}$ and Chris Meier*[a]
}

Adducts of $(8-(\mathrm{N}$-acetyl)-arylamines and 2'-deoxyadenosine were synthesised by palladium-catalysed $\mathrm{C}-\mathrm{N}$ cross-coupling chemistry. These $2^{\prime}-\mathrm{dA}$ adducts were converted into the corresponding 3 '-phosphoramidites and site-specifically incorporated into DNA oligonucleotides, which were characterised by mass spectrometry, UV thermal-stability assays and circular dichroism. These modified oligonucleotides were also used in EcoRI restriction assays and in primer-extension studies with three different DNA polymerases. The incorporation of the 2'dA lesion close to the EcoRI restriction site dramatically re- duced the susceptibility of the DNA strand to cleavage; this in dicates a significant local distortion of the DNA double helix. The incorporation of the acetylated C8-2'-dA-phosphoramidites into 20-mer oligonucleotides failed, however, because the $\mathrm{N}$ acetyl group was lost during the deprotection process. Instead the corresponding $\mathrm{C} 8 \mathrm{-NH}-2^{\prime}-\mathrm{dA}$-modified oligonucleotides were obtained. The effect of the C8-NH-arylamine-dA lesion on the replication by DNA polymerases was clearly dependent both on the polymerase used and on the arylamine-dA damage.

\section{Introduction}

Damage to DNA can result from several events such as irradiation (TT-photodimers), oxidation (8-oxo-G damage) and the action of chemical reagents (alkylating agents). These different forms of damage can have severe consequences for the biological system if they are not repaired by, for example, the base excision repair (BER) or nucleotide excision repair (NER) pathways. Such damage can lead to mutations and sometimes these mutations can even lead to the induction of carcinogenesis.

Poly- and monocyclic aromatic amines belong to the class of chemical carcinogens. The covalent chemical modification of the double helix seems to play a significant role in the potential induction of chemical carcinogenesis by aromatic amines of type 1 (Scheme 1). ${ }^{[1]}$ Aromatic amines are not toxic per se, however. The so-called ultimate carcinogens 6 are formed through metabolic processes.

Oxidation reactions are involved in the conversion of the aromatic amines into more hydrophilic compounds. One option involves the oxidation of the aromatic residues to afford phenol derivatives. The hydroxy groups are then esterified to give glucuronic esters. These esters enter into the detoxification pathway. However, cytochrome P450-catalysed oxidation of the amino groups leads to the corresponding $\mathrm{N}$-hydroxyarylamines $2,^{[2,3]}$ which, after esterification by $\mathrm{N}$-acetyltransferases (NATs) or transformation into sulfates by sulfotransferases (STs), form $\mathrm{N}$-acetoxy- or $\mathrm{N}$-sulfatoarylamines (e.g., 6). Through this process highly electrophilic metabolites are generated, and these are believed to be the ultimate carcinogen.

$\mathrm{N}$-Acetylated $\mathrm{N}$-arylamines $3 \mathrm{might}$ also play an important role. These can be formed from the aromatic amines 1 by enzymatic acetylation. Oxidation can then generate arylhydroxa- mic acids 5 . Further esterification again leads to highly reactive $N$-acetoxy compounds 6.

Solvolysis of compounds 6 generates the corresponding highly reactive $\mathrm{N}$-arylnitrenium ions 4 . The predominant reactions of the arylnitrenium ions 4 occur at the C8-positions of 2 -deoxyguanosine (dG) and 2'-deoxyadenosine (dA), leading to the corresponding $\mathrm{N}-\mathrm{H}$ or $\mathrm{N}-\mathrm{Ac}-\mathrm{C} 8$ adducts $7 \mathrm{a}$ and $7 \mathrm{~b}$ (Scheme 1). Moreover, $N^{2}-\mathrm{dG}$ - and $N^{6}-\mathrm{dA}$ adducts have been identified as minor products. ${ }^{[4,5]}$

Marroquin and Coyote reported that the binding preferences of $\mathrm{N}$-hydroxy- $\mathrm{N}$-acetylaminofluorene (AAF) for poly(G) and for poly(A) strands were about 6 to $1 .^{[5]}$ In their studies, two products were found in the case of $2^{\prime}-\mathrm{dA}$. $\mathrm{N}^{6}-\mathrm{AAF}-\mathrm{dA}$ was identified as the major product and the C8-AAF-dA adduct as a minor product. ${ }^{[6]}$

A first report on $\mathrm{N}$-acetylated adducts concerned the corresponding C8-dG adduct. Zhou and Romano reported on the synthesis of $\mathrm{N}$-acetylaminofluorene- $2^{\prime}-\mathrm{dG}$ adducts and their conversion into phosphoramidites. Standard ammonia deprotection after the oligonucleotide synthesis failed because of the presence of the base-labile $\mathrm{N}$-acetyl group, so the more

\footnotetext{
[a] Dr. Z. Szombati, Prof. Dr. C. Meier

Organic Chemistry, Department of Chemistry

Faculty of Sciences, University of Hamburg

Martin-Luther-King-Platz 6, 20146 Hamburg (Germany)

E-mail:chris.meier@chemie.uni-hamburg.de

[b] S. Baerns, Prof. Dr. A. Marx

Department of Chemistry and

Konstanz Research School of Chemical Biology

University of Konstanz

Universitätsstrasse 10, 78457 Konstanz (Germany)
} 


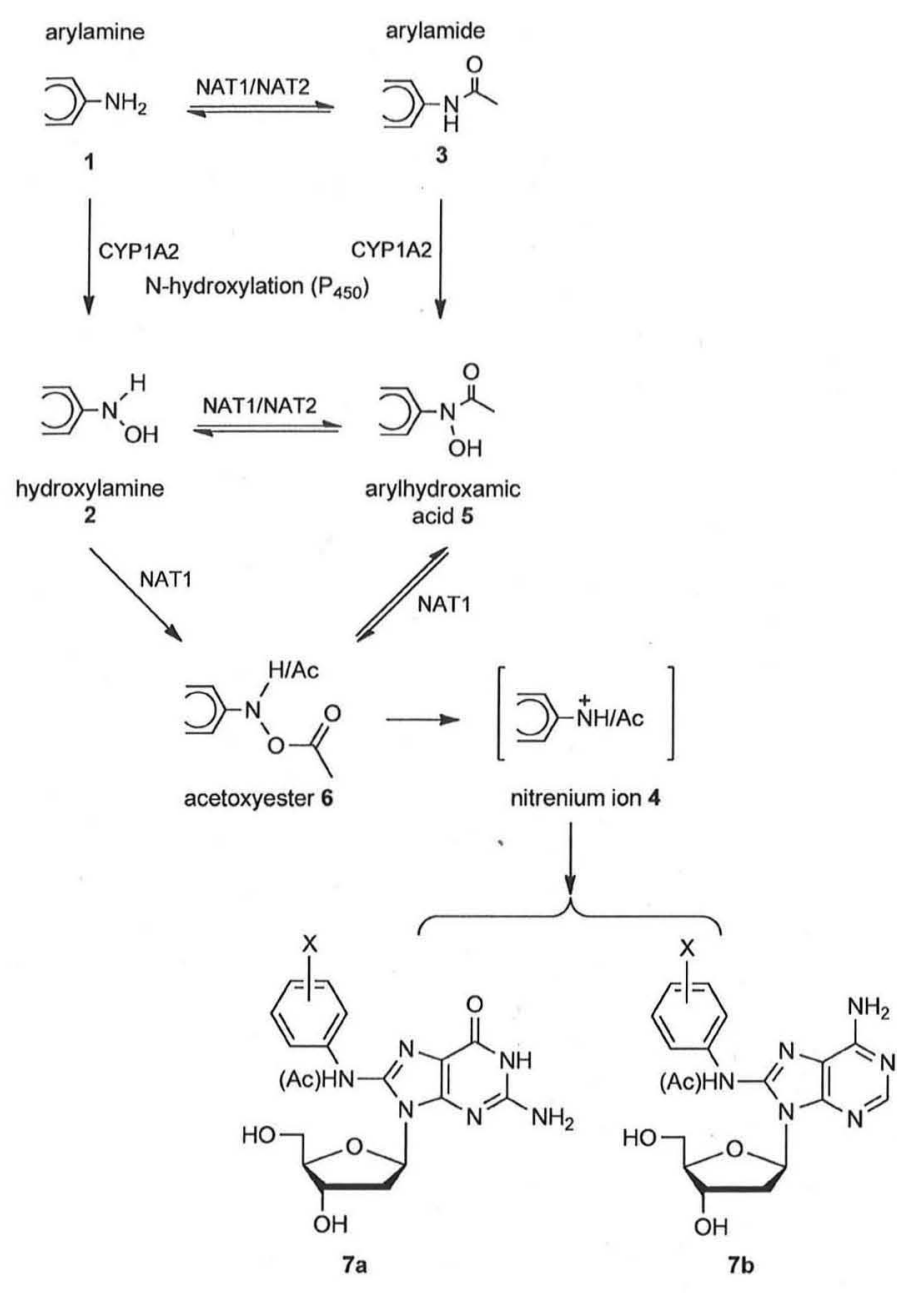

Scheme 1. Metabolism of aromatic amines, together with isolated and identified C8-arylamine-purine nucleoside adducts (NAT: N-acetyltransferase; CYP: cytochrome P450).

base-labile fluorenylmethoxycarbonyl (Fmoc) group was used as protecting group. ${ }^{[7,8]}$

Later, Gillet and Schärer introduced a new strategy for the introduction of the $\mathrm{N}$-acetyl group, the subsequent synthesis of the $\mathrm{N}$-acetylated dG-phosphoramidites and their site-specific incorporation into DNA oligonucleotides. They removed the protecting groups by overnight treatment with diisopropylamine (DIPA), because the loss of the $\mathrm{N}$-acetyl group was observed on application of ammonia..$^{[9,10]}$

Acetylated and non-acetylated adducts can cause different extents of local distortion in the DNA helix, due to significant differences in the conformations of the glycosidic bonds in the C8-modified 2'-dG-nucleosides (Scheme 2). ${ }^{[10,11]}$ Whereas C8$\mathrm{NH}-2^{\prime}$-dG adducts ( $\left.7 \mathrm{a}\right)$ preferred the anti conformations of their glycosidic bonds, placing the aromatic moieties in the major groove of the double helix and so should not in principle influence the hydrogen bridge stabilisation in the helix, the $\mathrm{N}$-acetylated $\mathrm{C} 8-2^{\prime}-\mathrm{dG}$ adducts (8) were found to prefer the syn conformations, which place the polycyclic aromatic systems within the double helix and displace the heterocyclic nucleobases from the helix into the major groove, resulting in loss of hydrogen bond stabilisation in the double helix. ${ }^{[11,12]}$ It was shown that C8-NAC-arylamine-dG damage in the DNA often caused frameshift mutations. ${ }^{[13]}$

In 2006 we published a first short report on the chemical synthesis of $\mathrm{C} 8-\mathrm{NH}$-arylamine-2'-dA adducts $[(\mathrm{NH}-\mathrm{aa})-\mathrm{dA}]$, their phosphoramidites and their sitespecific incorporation into oligonucleotides. ${ }^{[14]}$ In 2007 we reported a simple and efficient route to 8( $\mathrm{N}$-acetylarylamine)-2'-dG adducts [(NAc-aa)-dG] and their phosphoramidites. ${ }^{[15]}$ Until now, however, nothing has been published on the synthesis of $\mathrm{C} 8$-(NAC)arylamine adducts of $2^{\prime}-\mathrm{dA}$. Here, though, we report on the efficient synthesis of $\mathrm{dA}$ adducts of this type, the preparation of phosphoramidites and their sitespecific incorporation into oligonucleotides of short mixed sequences. In addition to $\mathrm{CD}$ and $T_{\mathrm{m}}$ measurements, the effects of these adducts on the cleavage of a damaged DNA duplex by the endonuclease EcoRI was investigated. Moreover, template 20-mer DNA oligonucleotides containing these lesions were prepared and studied in relation to primer extension by three different DNA polymerases.

\section{Results and Discussion}

Synthesis of 8-(N-acetyl)-arylamine-2'-deoxyadenosine [8-(NAc-aa)-dA] adducts

It was first attempted to introduce the $\mathrm{N}$-acetylated aromatic amines directly through the Pd-based crosscoupling chemistry that had been used previously. ${ }^{[9,14,16]}$ This failed, however, and only the C8-NH-dA adduct was formed, although in low chemical yields. Therefore, a linear synthesis was used and the reac-

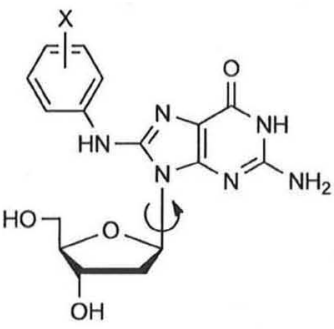

7a anti

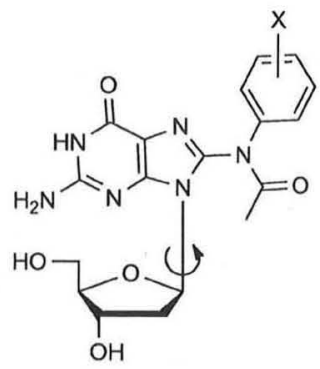

8 syn

Scheme 2. anti and syn conformations of the non-acetylated and the $\mathrm{N}$-acetylated adducts.

tion sequence depicted in Scheme 3 was found to be appropriate for the synthesis of phosphoramidites 17. Bromination of $2^{\prime}-\mathrm{dA}(9)$ at $\mathrm{C}^{[17]}$ and TBDMS protection gave product 11. Next, Pd-catalysed Buchwald-Hartwig cross-coupling led to C8$\mathrm{NH}$-aa-dA adducts $12 \mathrm{a}$-e. The exocyclic amino group was then doubly protected to give compounds 13 , which were used for acetylation. Best results were obtained when 4-DMAP (3 equiv) 


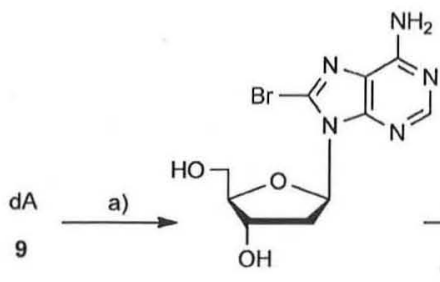

10

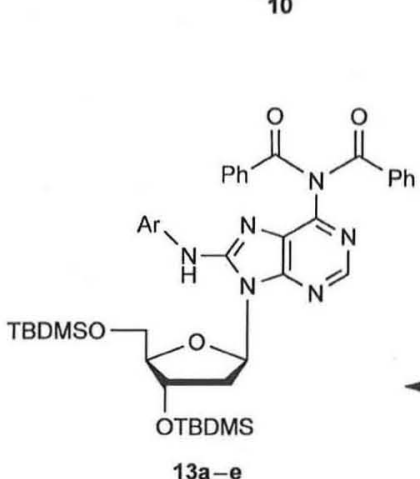

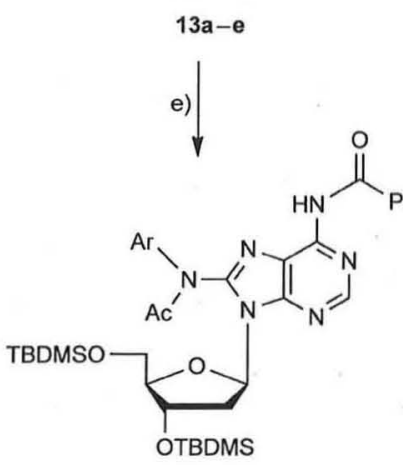

$14 a-e$

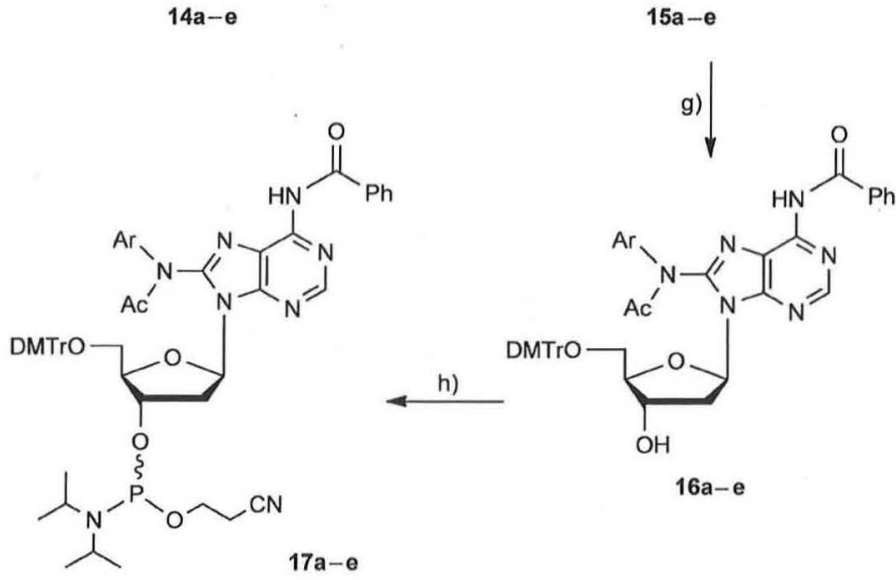

Scheme 3. Acetylation route and synthesis of the corresponding phosphoramidites 17 a) $\mathrm{Br}_{2}, \mathrm{NaOAc}$ buffer ( $\mathrm{pH} 5.0$ ), $\mathrm{RT}, 16 \mathrm{~h}, 83 \%$; b) TBDMSCl, imidazole, pyridine, RT, $16 \mathrm{~h}$, 92\%; c) aryl- $\mathrm{NH}_{2}, 30$ mol\% rac-BINAP, $10 \mathrm{~mol} \% \mathrm{Pd}_{2}(\mathrm{dba})_{3}, \mathrm{Cs}_{2} \mathrm{CO}_{3}, 1,2-\mathrm{DME}, 95^{\circ} \mathrm{C}, 24-48 \mathrm{~h}$ $88 \%$ a $(\mathrm{Ar}=$ phenyl), $98 \%$ b (=3,5-dimethylphenyl, $98 \%$ c (=4-methoxyphenyl), $90 \%$ d (=4-biphenyl), $91 \%$ e (=2-fluorenyl); d) BzCl, pyridine, RT, 16 h, $86 \%$ (a), 96\% (b), $90 \%$ (c), $95 \%$ (d), $82 \%$ (e); e) 4-DMAP, Ac 2 O, pyridine, RT, 72 h, $81 \%$ (a), $43 \%$ (b), $81 \%$ (c), $63 \%$ (d), $80 \%$ (e); f) i: $\mathrm{Et}_{3} \mathrm{~N}, \mathrm{Et}_{3} \mathrm{~N} \cdot 3 \mathrm{HF}, \mathrm{CH}_{2} \mathrm{Cl}_{2} / \mathrm{THF}, \mathrm{ii}: \mathrm{AcOH}, \mathrm{TBAF}, \mathrm{THF}, \mathrm{RT}, 24-48 \mathrm{~h}, 93 \%$ (a), $90 \%$ (b) $90 \%$ (c) $93 \%$ (d) $91 \%$ (e); g) DMTrCl, AgNO $_{3}$, pyridine, 3-16 h, RT, $52 \%$ (a), $67 \%$ (b), $62 \%$ (c), $66 \%$ (d), $70 \%$ (e); h) bis- $N, N^{\prime}$-diisopropylamino-(2-O-cyanoethyl)-phosphite, $\mathrm{DCl}, \mathrm{CH}_{2} \mathrm{Cl}_{2}, \mathrm{CH}_{3} \mathrm{CN}, 24 \mathrm{~h}, \mathrm{RT}, 66 \%$ (a), $55 \%$ (b), $63 \%$ (c), $66 \%$ (d), $66 \%$ (e). and $\mathrm{Ac}_{2} \mathrm{O}$ ( 3 equiv) in anhydrous pyridine were used. The reactions took $30-72 \mathrm{~h}$, during which one of the benzoyl groups was also cleaved to give compounds $14 \mathrm{a}-\mathrm{e}$. Adducts $14 \mathrm{a}-\mathrm{e}$ each showed a typical line broadening in the ' $\mathrm{H}$ NMR spectra at $298 \mathrm{~K}$, due to the amide bond resonance of the benzoyl group at the exocyclic amino group. Beland reported the same for the acetylated 2'-dG adducts. ${ }^{[18]}$ However, when the spectra were recorded at $328 \mathrm{~K}$ in $\left[\mathrm{D}_{6}\right] \mathrm{DMSO}$, the line broadening was significantly less.

Because of the introduced $\mathrm{N}$-acetyl group, the removal of the TBDMS groups had to be done under mild acid conditions. The use of tetra- $n$-butylammonium fluoride led to loss of the $\mathrm{N}$-acetyl groups. However, with buffering of the TBAF cleavage solution with acetic acid, the TBDMS groups were cleaved without loss of the $\mathrm{N}$-acetyl groups and gave compounds 15. The reactions with the $\mathrm{N}$-acetylated $2^{\prime}-\mathrm{dA}$ derivatives were four times slower than reactions performed with $2^{\prime}$-dG..$^{19,10]}$ Deprotection was also possible with $\mathrm{Et}_{3} \mathrm{~N} \cdot 3 \mathrm{HF}$, although the workup was found to be quite difficult.

The 5'-positions were then protected with DMTr groups and finally compounds 16 were converted into the corresponding phosphoramidites 17 (Scheme 3). In both cases, column chromatography was performed on $\mathrm{Al}_{2} \mathrm{O}_{3}$ (act. III).

In the synthesis summarised in Scheme 3, both C8$\mathrm{NH}-2^{\prime}$-dA adducts and C8-NAC-2'-dA adducts were prepared, and so the syn or anti preferences of the glycosidic bonds in the $2^{\prime}$-dA adducts were studied by NOESY-NMR spectroscopy. Figure $1 \mathrm{~A}$ shows an observed cross-peak between the $\mathrm{H}^{\prime}$ proton of the sugar and the $\mathrm{H} 2$ proton of the nucleobase that can be correlated to an anti orientation of the nucleobase. In contrast, cross-peaks between $\mathrm{H} 2$ and the 5 protons or the $5^{\prime}$ hydroxy proton typical of a syn conformation were absent. Figure 1B, however, shows an observed cross-peak between $\mathrm{H} 2$ and the $5^{\prime}-\mathrm{OH}$ group, which indicated a preferred syn conformation, whereas the $\mathrm{H} 2$ proton showed no cross-peak with $\mathrm{H} 1^{\prime}$.

Site-specific synthesis of oligonucleotides containing C8-(NAc-aa)-2'-dA adducts of different aromatic amines

For the incorporation of the $\mathrm{dA}$ adducts into oligonucleotides, phosphoramidites $17 \mathrm{a}$-e were dissolved in acetonitrile ( $0.1 \mathrm{~m}$ solutions), and their coupling steps were repeated three times, with total coupling efficiencies of $>90 \%$. In this way, three different sitespecifically modified oligonucleotide sequences were prepared: the Narl oligonucleotide [5'-d(CTCGGC ACCATC)-3'], a palindromic 12-mer EcoRI oligonucleotide [5'-d(GTAGAA TTCTAC)-3'] and a 20-mer oligonu- 


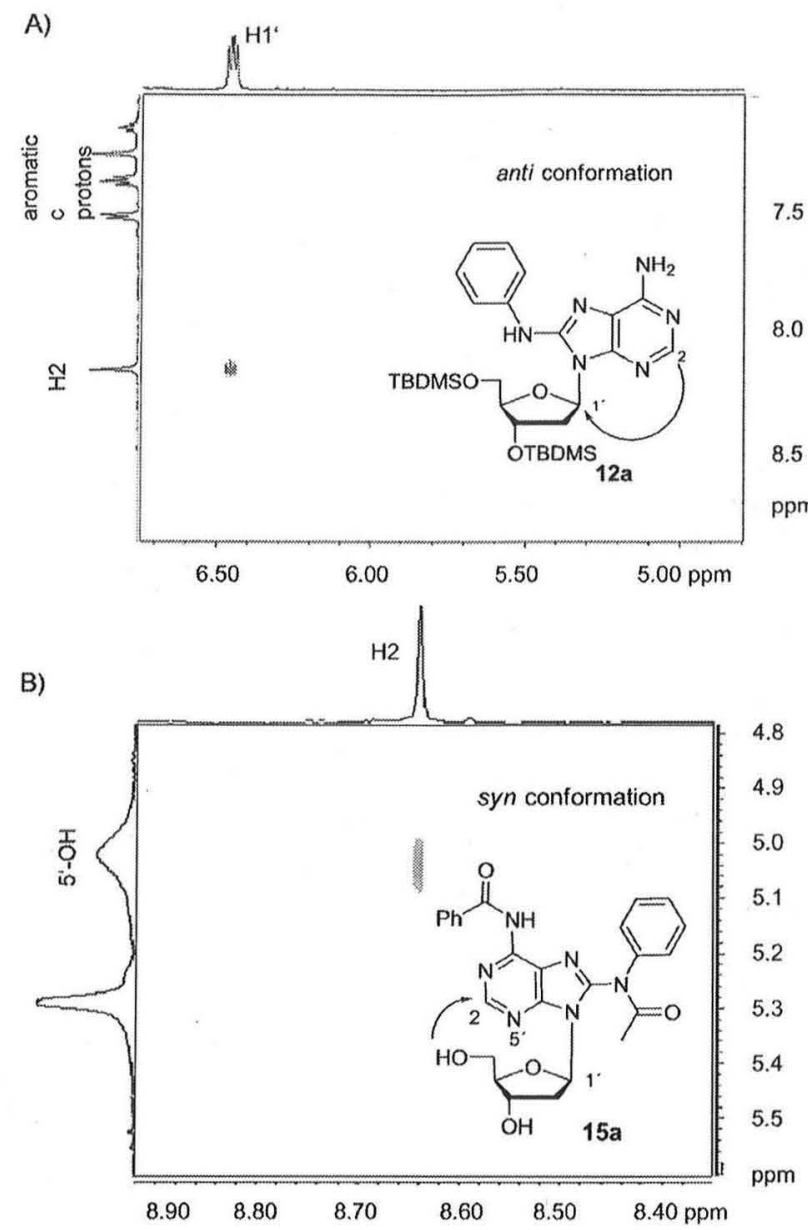

Figure 1. NOESY-NMR spectra of A) compound $12 \mathrm{a}$, and B) compound $15 \mathrm{a}$ in $\left[\mathrm{D}_{6}\right] \mathrm{DMSO}$ at $328 \mathrm{~K}$.

cleotide [5'-d(ACATAA GCATCT ACGACG CG)-3'] needed for DNA polymerase primer extension assays.

An important matter after the synthesis of the oligonucleotides was to find appropriate deprotection conditions because these adducts, particularly the $\mathrm{N}$-acetyl group, are known to be base-labile. Standard deprotection with ammonia ( $4 \mathrm{~h}$, $55^{\circ} \mathrm{C}$ ) was tried first, but failed; only the non-acetylated C8$\mathrm{NH}-2^{\prime}-\mathrm{dA}$ arylamine-modified oligonucleotide was isolated. Several variations of the ammonia treatment $(3 \rightarrow 24 \mathrm{~h}, \mathrm{RT} \rightarrow$ $55^{\circ} \mathrm{C}$ ) also failed. Finally, diisopropylamine (DIPA) in methanol was used both for the deprotection and for cleavage from the support. Two different concentrations (5 and 10\% DIPA) were tried, at room temperature and at $55^{\circ} \mathrm{C}$. Figure 2 shows attempts at deprotection with the C8-(NAc-phenyl)-2'-dA oligonucleotide $18 \mathrm{c}$. Clearly, at room temperature no oligonucleotide was detectable either with 5 or $10 \%$ DIPA (lanes 2 and 4; Figure 2). On overnight treatment (14 h) with DIPA (5 or $10 \%$ ) in $\mathrm{MeOH}$ at $55^{\circ} \mathrm{C}$, however, successful deprotection/cleavage was observed (lanes 1 and 3), but the acetylated (18c; $29.9 \mathrm{~min}$ ) and non-acetylated (18 b; $31.6 \mathrm{~min}$ ) oligonucleotides were obtained in comparable amounts. Although this was unexpected, due to the results reported previously, ${ }^{\left[{ }^{[9]}\right.}$ it was a posi-

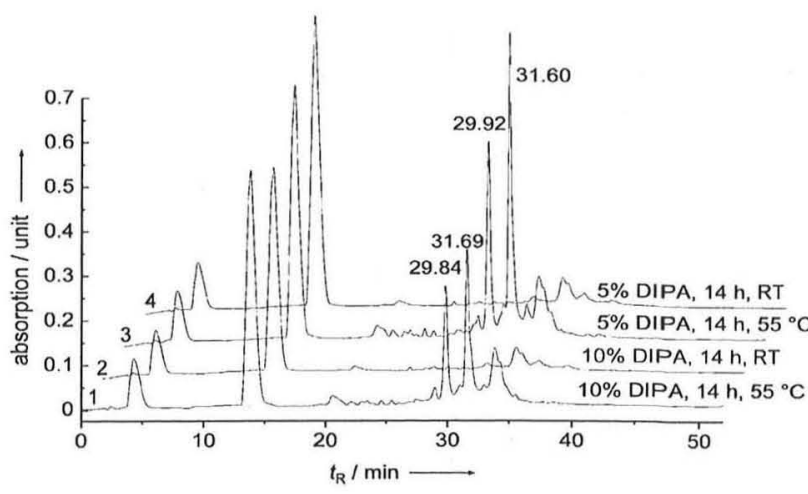

Figure 2. HPLC chromatogram of the Narl sequence containing a C8-(NACphenyl)-2'-dA lesion (18c) after treatment with DIPA. Peaks in lanes 1 and 3 with retention times of 29.84 and 29.92 min correspond to the target oligonucleotide $18 \mathrm{c}$ whereas the peaks at 31.69 and $31.60 \mathrm{~min}$ correspond to the $\mathrm{N}$-deacetylated $\mathrm{C} 8-(\mathrm{NH}-$ phenyl)-2'-dA damaged oligonucleotide (18b). Elution conditions: $\mathrm{CH}_{3} \mathrm{CN}$ gradient $0-23 \%$ in TEAA buffer ( $\mathrm{pH} 6.9$ ) over $50 \mathrm{~min}$.

tive side effect because both the $\mathrm{C} 8-(\mathrm{NH}-\mathrm{aa})-\mathrm{dA}$ - and the $\mathrm{C} 8$ (NAc-aa)-dA-modified oligonucleotides were obtained. Finally, $5 \%$ DIPA was used for deprotection/cleavage in all cases. In these reactions $\beta$-mercaptoethanol was added to prevent oxidative rearrangement in the presence of strong bases and oxygen, as observed previously for oligonucleotides containing the $\mathrm{C} 8-\mathrm{NH}$-aminofluorene- $2^{\prime}-\mathrm{dG}$ adduct. ${ }^{[19,20]}$ The obtained oligonucleotides were purified by reversed-phase HPLC and characterised by MALDI-TOF or ESI mass spectrometry (negative mode).

However, the isolation of the C8-(NAc-aa)-dA-containing Narl and EcoRI sequences was successful. In contrast, although further deprotection methods were unsuccessfully tested, none of the $\mathrm{N}$-acetylated, modified 20-mer oligonucleotides could be isolated, but the $\mathrm{C} 8 \mathrm{-NH}$-arylamine-modified 20 -mer oligonucleotides were obtained.

\section{Melting temperature $\left(T_{\mathrm{m}}\right)$ and circular dichroism studies}

All oligonucleotides were hybridised with the complementary strands and the thermal stabilities of the double strands of the C8-(NAc-aa)-dA adducts relative to those of the C8-NH-aa-dA adducts were measured by UV melting temperature analysis. The data for the Narl oligonucleotides $18 \mathbf{a}-\mathbf{i}$ are given in Table 1.

For the C8-NH-phenyl- and C8-NH-4-methoxyphenyl-containing damaged $2^{\prime}$-dA oligonucleotides $18 \mathrm{~b}$ and $18 \mathrm{~d}$, decreases of $\approx 8^{\circ} \mathrm{C}$ (relative to the $T_{\mathrm{m}}$ value of the unmodified Narl oligonucleotide $18 \mathrm{a}, T_{\mathrm{m}}=58.2^{\circ} \mathrm{C}$ ) were observed. Interestingly, for the oligonucleotide bearing the $\mathrm{C} 8-\mathrm{NH}$-biphenyl-2'-dA lesion $18 \mathrm{~h}$, no further significant decrease in thermal stability was observed. In the case of the 3,5-dimethylphenyl lesion $18 \mathrm{f}$, however, a decrease of $\approx 15^{\circ} \mathrm{C}$ was observed. Here, the influence of the two methyl groups in the 3,5-dimethylphenyl system on the thermal stability is more important than the second aromatic ring in the biphenyl residue. In the case of the $\mathrm{N}$-acetylated lesions, further decreases in thermal stability 


\begin{tabular}{|lc|}
\hline $\begin{array}{l}\text { Table 1. } T_{\mathrm{m}} \text { values of the duplexes formed with Narl oligonucleotides } \\
\text { 18a-i. }\end{array}$ & $T_{\mathrm{m}}\left[{ }^{\circ} \mathrm{C}\right]$ \\
\hline & 58.2 \\
Oligonucleotide & 50.1 \\
\hline 5'-d(CTC GGC ACC ATC)-3' (18 a) & 48.2 \\
5'-d(CTC GGC A(phenyl)CC ATC)-3' (18 b) & 51.0 \\
5'-d(CTC GGC A(Ac-phenyl)CC ATC)-3' (18 c) & 47.3 \\
5'-d(CTC GGC A(4-methoxyphenyl)CC ATC)-3' (18 d) & 45.1 \\
5'-d(CTC GGC A(AC-4-methoxyphenyl)CC ATC)-3' (18 e) & 42.1 \\
5'-d(CTC GGC A(3,5-dimethylphenyl)CC ATC)-3' (18 f) & 49.0 \\
5'-d(CTC GGC A(AC-3,5-dimethylphenyl)CC ATC)-3' (18 g) & 45.8 \\
5'-d(CTC GGC A(biphenyl)CC ATC)-3' (18 h) & \\
5'-d(CTC GGC A(AC-biphenyl)CC ATC)-3' (18 i) & \\
\hline \multicolumn{2}{l}{ Conditions: Narl oligonucleotide (1 nmol), complementary oligonucleo- } \\
tide strand (1 nmol), phosphate buffer (pH 7.2, 10 mm), NaCl (140 mm), \\
EDTA (1.0 mM).
\end{tabular}

of $\approx 2-4^{\circ} \mathrm{C}$ relative to their non-acetylated counterparts was determined.

For the palindromic EcoRI oligonucleotides, the effect on the $T_{\mathrm{m}}$ values was expected to be more pronounced, because after duplex formation a lesion is present in each strand. Two different oligonucleotide modifications differing in the positions of the lesions were prepared. In one set of oligonucleotides the lesions were at the cleavage position in the restriction region (fifth base from the $5^{\prime}$-end) whereas the other set of oligonucleotide had the lesions only one base before the cleavage site (third base from the $5^{\prime}$-end). The $T_{\mathrm{m}}$ values are summarised in Table 2.

\begin{tabular}{|c|c|}
\hline Oligonucleotide & $T_{\mathrm{m}}\left[{ }^{\circ} \mathrm{C}\right]$ \\
\hline $5^{\prime}-\mathrm{d}($ GTA GAA TTC TAC)-3' (19a) & 41.7 \\
\hline $5^{\prime}-\mathrm{d}(\mathrm{GTA}$ GA(phenyl)A TTC TAC)-3' (19 b) & 41.3 \\
\hline $5^{\prime}-\mathrm{d}(\mathrm{GTA}$ GA(Ac-phenyl)A TTC TAC)-3' (19c) & 41.5 \\
\hline $5^{\prime}-\mathrm{d}(\mathrm{GTA}$ GA(4-methoxyphenyl)A TTC TAC)-3' (19d) & 32.6 \\
\hline $5^{\prime}-\mathrm{d}(\mathrm{GTA}$ GA(AC-4-methoxyphenyl)A TTC TAC)-3' (19e) & 34.3 \\
\hline $5^{\prime}-\mathrm{d}(\mathrm{GTA}$ GA(biphenyl)A TTC TAC)-3' (19 f) & 42.8 \\
\hline $5^{\prime}$-d(GTA GA(Ac-biphenyl)A TTC TAC)-3' (19g) & 40.2 \\
\hline $5^{\prime}-\mathrm{d}(\mathrm{GTA}$ (phenyl) GAA TTC TAC)-3' (19 h) & 30.1 \\
\hline $5^{\prime}$-d(GTA(AC-phenyl) GAA TTC TAC)-3' (19i) & 31.5 \\
\hline $5^{\prime}-\mathrm{d}(\mathrm{GTA}$ (4-methoxyphenyl) GAA TTC TAC)-3' (19j) & 29.1 \\
\hline $5^{\prime}-\mathrm{d}(\mathrm{GTA}(\mathrm{AC}-4-$ methoxyphenyl) GAA TTC TAC)-3' (19k) & 32.0 \\
\hline $5^{\prime}-\mathrm{d}(\mathrm{GTA}$ (biphenyl) GAA TTC TAC)-3' (19l) & 33.4 \\
\hline $5^{\prime}$-d(GTA(Ac-biphenyl) GAA TTC TAC)-3' (19 m) & 33.6 \\
\hline
\end{tabular}

Surprisingly, there was almost no thermal destabilisation (relative to the unmodified reference oligonucleotide 19a) when the lesion was introduced in the cleavage site, except in cases involving the 4-methoxyphenyl residue (19d, 19e). Moreover, there was no effect of acetylation at the nitrogen atom on the duplex stability. Significant decreases in thermal stability were observed, however, when the lesions were introduced closer to the $5^{\prime}$-ends of the oligonucleotides $(19 \mathrm{~h}-\mathrm{m})$. As above, almost no differences between the $\mathrm{NH}$ - and NAc-arylamine-dA lesions were found. Here the destabilisation is more pronounced because the hybridisation at the end of a duplex is less stable, and this effect is attenuated if an additional structural distortion is present. The hybridisation data for the 20mer oligonucleotides $\mathbf{2 0} \mathbf{a}-\mathbf{j}$ are summarised in Table 3 .

\begin{tabular}{|c|c|}
\hline Oligonucleotide & $T_{\mathrm{m}}\left[{ }^{\circ} \mathrm{C}\right]$ \\
\hline $5^{\prime}-d(A C A$ TAA GCA TCT ACG ACG CG)-3' (20a) & 64.8 \\
\hline $5^{\prime}-\mathrm{d}(\mathrm{ACA}$ TA(phenyl)A GCA TCT ACG ACG CG)-3' (20 b) & 61.1 \\
\hline $5^{\prime}$-d(ACA TA(4-methoxyphenyl)A GCA TCT ACG ACG CG)-3' (20 d) & 60.8 \\
\hline $5^{\prime}$-d(ACA TA(3,5-dimethylphenyl)A GCA TCT ACG ACG CG)-3' (20 f) & 57.8 \\
\hline $5^{\prime}-\mathrm{d}($ ACA TA(biphenyl)A GCA TCT ACG ACG CG)-3' (20 h) & 58.7 \\
\hline $5^{\prime}-\mathrm{d}(\mathrm{ACA}$ TA(fluorenyl)A GCA TCT ACG ACG CG)-3' (20j) & 61.6 \\
\hline \multicolumn{2}{|c|}{$\begin{array}{l}\text { Conditions: } 20 \text {-mer oligonucleotide }(1 \mathrm{nmol}) \text {, complementary oligonu- } \\
\text { cleotide strand }(1 \mathrm{nmol}) \text {, phosphate buffer }(\mathrm{pH} 7.2,10 \mathrm{~mm}), \mathrm{NaCl} \\
(140 \mathrm{~mm}), \text { EDTA }(1.0 \mathrm{~mm}) \text {. }\end{array}$} \\
\hline
\end{tabular}

The double strand of the unmodified reference oligonucleotide showed a thermal stability of about $65^{\circ} \mathrm{C}$. The $\mathrm{N}$-phenyl, the $\mathrm{N}$-(4-methoxyphenyl) and the $\mathrm{N}$-fluorenyl- $\mathrm{NH}$ adducts decreased the $T_{\mathrm{m}}$ value by $\approx 3-4{ }^{\circ} \mathrm{C}$. The strongest destabilisation was again found for the 3,5-dimethylaniline lesion-20 f-followed by the biphenylamine residue in $20 \mathrm{~h}$.

In addition, the circular dichroism (CD) spectra of all synthesised oligonucleotides as hybrids with the complementary strands were recorded to verify the overall $B$-type DNA conformations of the lesion-containing DNA hybrids and the unmodified reference duplex. In the case of the Narl sequence 18ai no conformational difference between the reference oligonucleotide $18 \mathrm{a}$ and the oligonucleotides containing C8-NAC-aaand $\mathrm{C} 8-\mathrm{NH}$-aa-dA was observed, because in each case a positive Cotton effect was observed at $273 \mathrm{~nm}$ together with a negative, less pronounced one at $240 \mathrm{~nm}$ typically found for B-type DNA. However, the CD curves were less shaped, which indicates less structured helixes. In addition, no overall conformational differences were observed in the cases either of the EcoRI oligonucleotides (Figure 3) of the 20-mer duplexes.

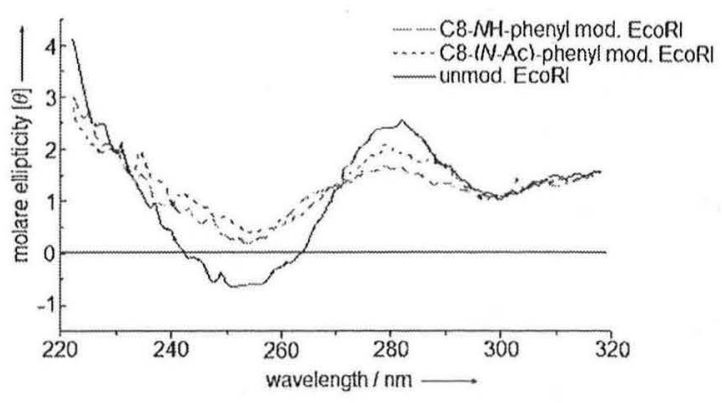

Figure 3. CD spectra of EcoRI oligonucleotides $19 a-c$. 


\section{EcoRI restriction assay}

To investigate the effects of arylamine-dA-modified oligonucleotides on endonuclease restriction, an EcoRI restriction assay was performed. ${ }^{[16]}$ The enzyme EcoRI cleaves both strands of a DNA double helix. We have shown before that, under the reaction conditions used here, the enzyme EcoRl cleaved the self-complementary, undamaged 12-mer oligonucleotide 19a [5'-d(GTA GAA TTC TAC)-3'] into a tetramer (GTAG) and an octamer strand (AATTCTAC). ${ }^{[16]}$ For oligonucleotide 19a, a half-life of $2.45 \mathrm{~h}$ was determined ( 270 units of enzyme, DTT buffer at $23^{\circ} \mathrm{C}$ ). The half-life was calculated as described previously. ${ }^{[21]}$ When the same restriction assay was performed with oligonucleotides $19 \mathrm{~b}-\mathrm{f}$ under identical experimental conditions, no cleavage of any of these lesion-containing oligonucleotides was detected. As an example, the experiment with $19 \mathrm{e}$ followed over $24 \mathrm{~h}$ is illustrated in Figure 4.

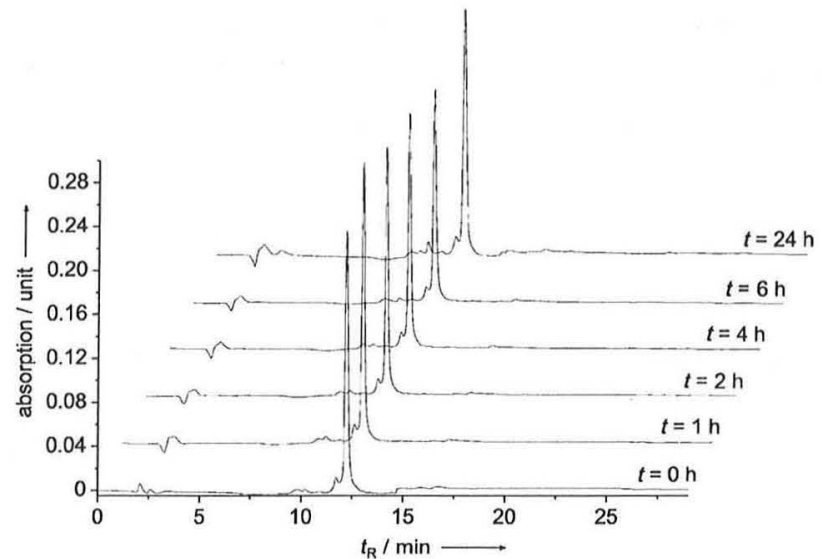

Figure 4. HPLC chromatogram for the EcoRI restriction assay with $19 \mathrm{e}$.

Clearly, the presence of the C8-(NH-aa)- or C8-(NAc-aa)-dA damage in the cleavage site caused severe conformational distortion and steric blocking, thus making the enzyme unable to bind and/or to cleave the DNA double strand. However, with a shift of the modification site only one position away from the cleavage site, restriction was observed but at lower rates (Figure 5). For the $\mathrm{C} 8-\mathrm{NH}$-aa-dA damaged oligonucleotides half-lives of $3.3 \mathrm{~h}$ were calculated in the cases of aniline and 4methoxyaniline, whereas the polycyclic 4-aminobiphenyl damage led to a half-life of $2.9 \mathrm{~h}$. In the case of the N-acetylated modification $19 \mathrm{~m}$ the EcoRl restriction assay showed a surprising effect; it seemed that the slow enzymatic reaction even stopped after $6 \mathrm{~h}$, with no change being observable after $9 \mathrm{~h}$ of incubation relative to the values obtained after $6 \mathrm{~h}$. Addition of fresh enzyme after $9 \mathrm{~h}$ led to further cleavage, which again stopped after several hours. The same effect was observed in the case of the $\mathrm{N}$-acetylated monocyclic lesions $19 \mathrm{i}$ and $19 \mathrm{k}$. This behaviour was not seen with the corresponding oligonucleotides containing the $\mathrm{C} 8-(\mathrm{NH}-\mathrm{aa})-\mathrm{dA}$ lesions. These results suggest inhibition of the enzyme by an unknown mechanism. Table 4 summarises the calculated half-lives, all calculated with the assumption of first-order reactions.

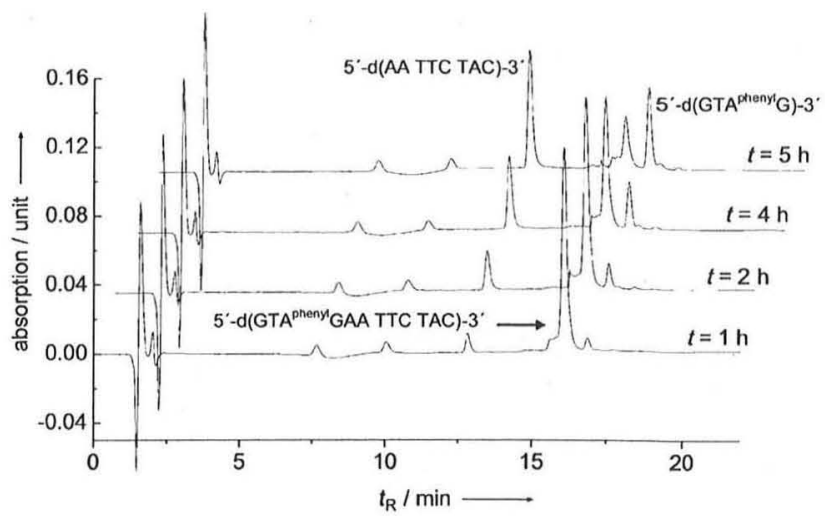

Figure 5. HPLC chromatogram for the EcoRI restriction assay with $19 \mathrm{~h}$.

\begin{tabular}{|c|c|}
\hline Oligonucleotide & $t_{1 / 2}$ \\
\hline 5'-GTAGAATTCTAC-3' (19a) & 2.5 \\
\hline $5^{\prime}-\mathrm{d}(\mathrm{GTA}$ GA(phenyl)A TTC TAC)-3' (19 b) & no cleavage \\
\hline $5^{\prime}$-d(GTA GA(Ac-phenyl)A TTC TAC)-3' (19c) & no cleavage \\
\hline $5^{\prime}$-d(GTA GA(4-methoxyphenyl)A TTC TAC)-3' (19d) & no cleavage \\
\hline $5^{\prime}$-d(GTA GA(AC-4-methoxyphenyl)A TTC TAC)-3' (19e) & no cleavage \\
\hline $5^{\prime}-d(G T A$ GA(biphenyl)A TTC TAC)-3' (19 f) & no cleavage \\
\hline $5^{\prime}$-d(GTA GA(AC-biphenyl)A TTC TAC)-3' (19 g) & no cleavage \\
\hline $5^{\prime}-\mathrm{d}(\mathrm{GTA}($ phenyl) GAA TTC TAC)-3' (19h) & 3.3 \\
\hline $5^{\prime}-\mathrm{d}(\mathrm{GTA}(\mathrm{Ac}-$-phenyl) GAA TTC TAC)-3' (19i) & inhibition \\
\hline $5^{\prime}$-d(GTA(4-methoxyphenyl) GAA TTC TAC)-3' (19j) & 3.3 \\
\hline $5^{\prime}-\mathrm{d}(\mathrm{GTA}(\mathrm{AC}-4$-methoxyphenyl) GAA TTC TAC)-3' (19k) & inhibition \\
\hline $5^{\prime}$-d(GTA(biphenyl) GAA TTC TAC)-3' (19l) & 3.1 \\
\hline $5^{\prime}$-d(GTA(AC-biphenyl) GAA TTC TAC)-3' (19 m) & inhibition \\
\hline
\end{tabular}

\section{Primer-extension assay}

As investigations of other DNA adducts have shown, covalent DNA modifications significantly hamper the selectivity and efficiency of DNA synthesis by replicative DNA polymerases, whereas other DNA polymerases are effective in performing lesion bypass beyond the site of damage. ${ }^{[22]}$ Here, three DNA polymerases from different DNA polymerase families were studied with regard to their effectiveness in bypassing the C8$\mathrm{NH}$-arylamine-dA lesions (Figure 6).

The experiments were performed under standing-start conditions with a ${ }^{32} \mathrm{P}$-labelled primer/template complex (Figure 6). Single incorporations were examined in order to gain insights into the impact of the lesion on selectivity, whereas additional experiments with all four dNTPs were used to study lesion bypass capability.

Human DNA polymerase $\beta$, a member of the DNA polymerase $X$ family involved in DNA repair, was investigated first. ${ }^{[23]}$ Incorporation opposite the DNA lesion was successful and the canonical dTTP was always preferably chosen. In the case of the 4-aminobiphenyl-dA lesion, however, misinsertion of the non-canonical dGMP was also observed to some extent. In the presence of all four dNTPs, complete elongation was observed in the reference experiment, as expected. Interestingly, in the 
$3^{\circ}-d$ (GCG CAG CAT CTA CGAATA CA $-5^{\prime}$
$5^{\circ}-d$ (GCG GTC GTA GAT GCT

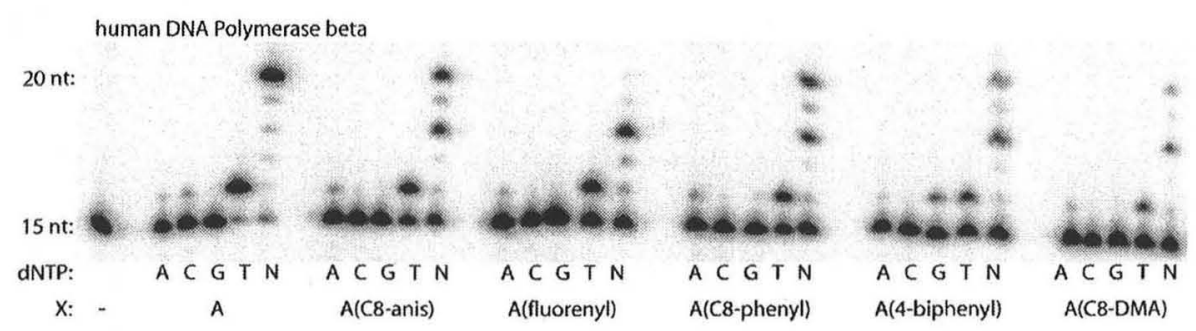

Dpo4 DNA Polymerase

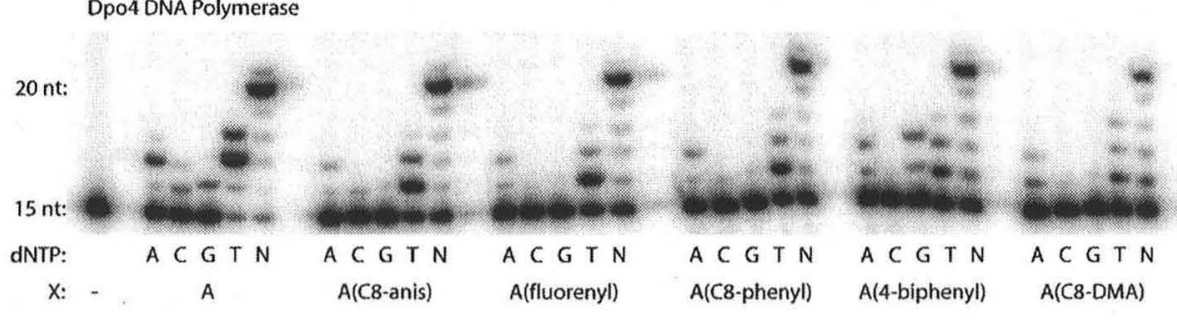

Pfu DNA Polymerase

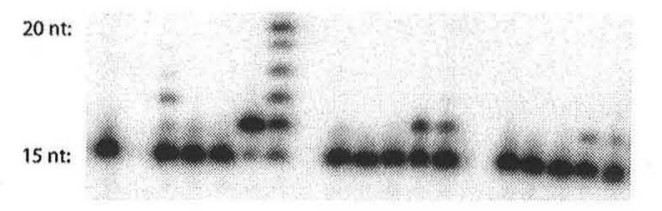

dNTP: ACGTN ACGTN ACGTN

$X:$ - $A$ A(C8-anis) A(fluorenyl)

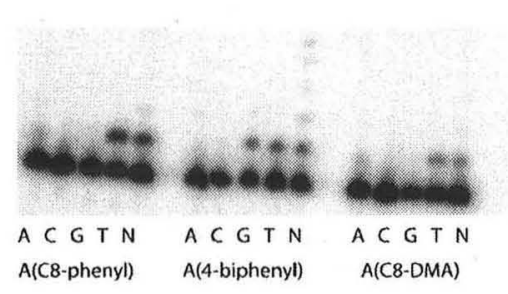

Figure 6. C8-Arylamine-2'-dA lesions and DNA replication.

case of the lesion-containing oligonucleotides, products two nucleotides shorter were also observed beside the full-length products. In the case of the 2-aminofluorene-dA damage this was even the predominant replication product. The DNA synthesis proceeded with less efficiency than in the case of the unmodified reference.

Next, the Sulfolobus solfataricus P2 DNA polymerase IV (Dpo4), which often serves as a functional and structural model for Y-family DNA polymerases, was studied. ${ }^{[24]}$ Again, the canonical dT was incorporated in all cases of single-incorporation experiments and again the non-canonical dGTP was added opposite the 4-aminobiphenyl lesion. Unlike the first DNA polymerase, Dpo4 was effective in bypassing all the lesions when all four nucleotides were employed, although again with reduced efficiency.

Finally, the high-fidelity Pyrococcus furiosus (Pfu) DNA polymerase $\left(3^{\prime} \rightarrow 5^{\prime}\right.$ exonuclease-deficient mutant), ${ }^{[25,26]}$ a replicative DNA polymerase belonging to sequence family $B$, was investigated. The canonical nucleotide TMP was incorporated predominantly opposite to the modified $\mathrm{dA}$, but in case of the C8-NH-4-aminobiphenyl lesion incorporation of the non-canonical dGMP was also observed to some extent. In contrast with the two other DNA polymerases the incorporation of nucleotides paused immediately after insertion opposite the lesions.
These experiments established that the lesions have marked influences on high-fidelity polymerases due to the structural changes at the damaged sites. At the very least, considerable reductions in the elongation efficiencies were always detected.

A few differences from our previous study based on $\mathrm{C} 8 \mathrm{-NH}-$ arylamine adducts of 2'-deoxyguanosine ${ }^{[16]}$ were identified. In the cases of 4-aminobiphenyl and anisidine, DNA polymerase $\beta$ incorporated only the canonical $\mathrm{dC}$ and full elongation of the primer was observed. With Dpo4 DNA polymerase, however, despite the selective incorporation of $\mathrm{dC}$, a pronounced slowing of the replication was observed after the dC incorporation. Finally, Pfu DNA polymerase led to significant misincorporation opposite the $d G$ lesion. In addition to $d C, d A$ and $d T$ were also found to be incorporated by the enzyme and again a pronounced slowing after the elongation was observed. ${ }^{[16]}$ Interestingly, the dA and the dG lesions caused different misincorporations in different amounts. However, in the cases of misincorporation, the $\mathrm{dA}$ lesion led to the introduction of $d G$ instead of $d T$ whereas in the case of the $d G$ lesion $d A$ was incorporated instead of $\mathrm{dC}$. The consequence is that in both lesions a pair of purine nucleosides is produced at the site of DNA damage.

\section{Conclusion}

A procedure for the synthesis of 8 - $(\mathrm{N}$-acetyl)-arylamine- $\mathrm{dA}$ phosphoramidites has been developed. The C8-arylamine moieties were efficiently introduced by using $\mathrm{Pd}$ cross-coupling chemistry. The corresponding phosphoramidites were site-specifically incorporated into two different 12-mer oligonucleotides. Interestingly, after the automated DNA synthesis, the Nacetyl-arylamine damaged oligonucleotide and its $\mathrm{NH}$-arylamine counterpart were always isolated, due to the great sensitivity of the $\mathrm{N}$-acetyl group under alkaline conditions. For the Narl and the self-complementary EcoRI sequences, both the thermal stabilities and CD spectra were determined. In all cases, marked decreases in the $T_{\mathrm{m}}$ values were detected for the lesion-containing DNA strands; this point to marked distortion of the double helix, resulting in weaker hybridisation between the two strands. The decreases were even stronger for the $\mathrm{N}$ acetyl-arylamine damage than for the $\mathrm{NH}$-arylamine lesions. 
Whether or not this observation can be correlated with the detected differences in the syn/anti preferences of the glycosidic bonds in the dA adducts still has to be confirmed. Nevertheless, only minimal differences in the CD spectra of the compounds modified with acetylated aromatic amines and those modified with non-acetylated aromatic amines were measured. The lesion-containing oligonucleotides were found to be resistant to digestion by EcoRI if the modification was present at the cleavage site of the EcoRl enzyme. This might indicate marked local distortion of the DNA hybrid at the modification site, either blocking the cleavage of the double strand or preventing binding of the restriction enzyme. This effect was independent of the C8-NAc-arylamine-dA damage. Previously, $\mathrm{NH}$ adducts of $d A$ or $d G$ had also shown the same behaviour. However, irrespective of whether a monocyclic or a polycyclic DNA lesion was investigated, incorporation of the lesion just one nucleotide prior to the EcoRI cleavage site only slightly reduced the half-life of this enzymatic digestion. It thus appears that the arylamine adducts cause local but not long-ranging perturbation of helix recognition. Alternatively, just the steric bulk of the $\mathrm{dA}$ adduct in the restriction site might be the reason for misbinding or failure of enzyme cleavage. Finally, it was shown that the bypass ability of a lesion in a DNA strand depended strongly on the DNA polymerase used. In most cases, the fidelity of nucleotide incorporation opposite the lesion was not hampered. However, the abilities of the polymerases to bypass the lesions were quite different. Only the strong carcinogen 4-aminobiphenyl showed a different effect on the replication. With all three polymerases, marked incorporation of dGTP beside the canonical TTP was detected, leading to point mutations. The reason for this $T \rightarrow d G$ misincorporation is still unknown. Further work to gain insights into the structural changes in the DNA helix produced by the C8-arylamine adducts is currently underway in our laboratories.

\section{Experimental Section}

General methods: All air- or water-sensitive reactions were performed in flame-dried glassware under nitrogen. Commercial solvents and reagents were used without further purification with the following exceptions: 1,2-dimethoxy ethane (1,2-DME) was distilled from potassium under nitrogen, whereas pyridine, dichloromethane and acetonitrile were distilled from calcium hydride under nitrogen. Water was purified with a Milli-Q water system. NMR spectra are reported relative to the corresponding solvent peaks. 'H NMR: $2.50 \mathrm{ppm}$ ([D $]$ DMSO), $7.26 \mathrm{ppm} \quad\left(\mathrm{CDCl}_{3}\right), 3.31 \mathrm{ppm}$ $\left(\mathrm{CD}_{3} \mathrm{OD}\right)$ and $7.16\left(\mathrm{C}_{6} \mathrm{D}_{6}\right) .{ }^{13} \mathrm{C}$ NMR: $39.52 \mathrm{ppm}$ ([D 6 DMSO), $77.16 \mathrm{ppm}\left(\mathrm{CDCl}_{3}\right), 49.0 \mathrm{ppm}\left(\mathrm{CD}_{3} \mathrm{OD}\right)$ and $128.06\left(\mathrm{C}_{6} \mathrm{D}_{6}\right)$. Thin-layer chromatography was performed on aluminium sheets coated with silica gel (Merck, $60 \mathrm{~F}_{254}$ ). Mass spectra were recorded with VG Analytical VG/70-250 F (FAB, HR-FAB), Finnigan ThermoQuest MAT $95 \mathrm{XL}$ (ESI, HR-ESI), Agilent Technologies 6224 TOF LC/MS 1200 series (HPLC-ESI-MS) and Bruker BiFlex III (MALDI-TOF) instruments.

\section{8-Bromo-3', 5'-O-bis(tert-butyldimethylsilyl)-2'-deoxyadenosine}

(11): 8-Bromo-2'-deoxyadenosine (10) $(3.0 \mathrm{~g}, 9.1 \mathrm{mmol})$ was subjected three times to coevaporation of the volatiles with anhydrous pyridine $(5 \mathrm{~mL})$ and then suspended in anhydrous pyridine $(30 \mathrm{~mL})$ under nitrogen. TBDMSCl $(4.1 \mathrm{~g}, 27.3 \mathrm{mmol})$ and imidazole $(1.9 \mathrm{~g}$,
$27.3 \mathrm{mmol}$ ) were then added and the reaction mixture was stirred for $16 \mathrm{~h}$ at room temperature. The reaction was stopped by addition of $\mathrm{CH}_{2} \mathrm{Cl}_{2}$. The mixture was washed once with water and once with brine. The solvent was removed in vacuo. The residue was coevaporated with toluene $(3 \times)$. The residue was recrystallised from $\mathrm{CH}_{3} \mathrm{CN}$ to give 11 as a colourless solid ( $3.4 \mathrm{~g}, 7.8 \mathrm{mmol}, 85 \%$ ). M.p. $139^{\circ} \mathrm{C} ;[\alpha]_{589 \mathrm{~nm}}^{22}=-8.21\left(c=0.67, \mathrm{CHCl}_{3}\right) ;{ }^{1} \mathrm{H} \mathrm{NMR}\left(400 \mathrm{MHz}, \mathrm{CDCl}_{3}\right)$ : $\delta=8.25(\mathrm{~s}, 1 \mathrm{H}), 6.34(\mathrm{t}, J=6.7 \mathrm{~Hz}, 1 \mathrm{H}), 5.59(\mathrm{~s}, 2 \mathrm{H}), 4.87(\mathrm{dt}, J=5.8$, $3.8 \mathrm{~Hz}, 1 \mathrm{H}), 3.88-3.97(\mathrm{~m}, 2 \mathrm{H}), 3.62-3.69(\mathrm{~m}, 2 \mathrm{H}), 2.23$ (ddd, $J=$ $13.2,6.9,4.3 \mathrm{~Hz}, 1 \mathrm{H}), 0.93(\mathrm{~s}, 9 \mathrm{H}), 0.82(\mathrm{~s}, 9 \mathrm{H}), 0.14(\mathrm{~s}, 6 \mathrm{H}),-0.01$ $(\mathrm{s}, 3 \mathrm{H}),-0.05 \mathrm{ppm}(\mathrm{s}, 3 \mathrm{H}) ;{ }^{13} \mathrm{C}$ NMR (101 MHz, $\left.\mathrm{CDCl}_{3}\right): \delta=154.3$, $152.7,151.2,128.5,116.1,87.9,86.5,72.5,62.8,36.9,26.0,25.8$, 18.2, 18.1, $-4.7 \mathrm{ppm}$; IR (KBr): $\tilde{v}=3830,3182,2954,2884,2856$, 1661, 1570, 1492, 1320, 1257, 1110, 838, 776, 669, 597, $554 \mathrm{~cm}^{-1}$; MS (FAB): $\mathrm{m} / \mathrm{z}$ calcd: $557.18\left[\mathrm{M}^{+}\right.$; found. 557.12 .

General Procedure I (GP-I) for the amination of 8-bromo-3', $5^{\prime}-0$ bis(tert-butyldimethylsilyl)-2'-deoxyadenosine derivatives to afford compounds 12a-d: Racemic 2,2'-bis(diphenylphosphino)1,1'-binaphthyl (rac-BINAP, $30 \mathrm{~mol} \%$ ) and tris(dibenzylidenacetone)dipalladium $(0)\left(\mathrm{Pd}_{2}(\mathrm{dba})_{3} ; 10 \mathrm{~mol} \%\right)$ were suspended in anhydrous 1,2-dimethoxyethane $(50 \mathrm{~mL})$ and the mixture was stirred for one hour at room temperature. Compound 11, the amine ( 2.5 equiv) and $\mathrm{Cs}_{2} \mathrm{CO}_{3}$ ( 1.5 equiv) were then added and the mixture was stirred under reflux until the reaction was complete (24-48 h). The reaction mixture was allowed to cool to room temperature, and saturated sodium hydrogen carbonate solution $(1 \mathrm{~mL})$ was added. After the addition of brine $(10 \mathrm{~mL})$, the layers were separated and the aqueous layer was extracted with ethyl acetate $(3 \times 10 \mathrm{~mL})$. The combined organic layers were washed with brine $(2 \times 10 \mathrm{~mL})$ and with a mixture of brine $(10 \mathrm{~mL})$ and water $(2 \mathrm{~mL})$. The organic layer was dried over sodium sulfate and the solvent was removed in vacuo. Purification of the residue by flash chromatography on silica gel, with elution with ethyl acetate in petroleum ether $(10 \rightarrow$ $35 \%)$, gave the compounds 12 .

8- $\mathrm{N}$-Phenyl-3',5'-O-bis(tert-butyldimethylsilyl)-2'-deoxyadenosine (12 a): GP-I was used with 11 (3.00 g, $5.38 \mathrm{mmol}$ ) and $\mathrm{PhNH}_{2}$, which afforded the desired product as a pale yellow foam $(2.36 \mathrm{~g}$, $4.13 \mathrm{mmol}, 77 \%)$. M.p. $70^{\circ} \mathrm{C} ; \quad[\alpha]_{589 \mathrm{~nm}}^{20}=11.4 \quad\left(c=0.25, \mathrm{CHCl}_{3}\right)$; ${ }^{1} \mathrm{H}$ NMR $\left(400 \mathrm{MHz} \mathrm{CDCl}_{3}\right): \delta=8.19(\mathrm{~s}, 1 \mathrm{H}), 7.87(\mathrm{~s}, 1 \mathrm{H}), 7.57$ (d, $\left.J_{\mathrm{H}, \mathrm{H}}=8.0 \mathrm{~Hz}, 2 \mathrm{H}\right), 7.34\left(\mathrm{t}, J_{\mathrm{H}, \mathrm{H}}=7.7 \mathrm{~Hz}, 2 \mathrm{H}\right), 7.08\left(\mathrm{t}, J_{\mathrm{H}, \mathrm{H}}=7.3 \mathrm{~Hz}, 1 \mathrm{H}\right)$, $6.45\left(\mathrm{dd}, J_{\mathrm{H}, \mathrm{H}}=8.5 \mathrm{~Hz}, 5.3,1 \mathrm{H}\right), 4.55\left(\mathrm{dt}, J_{\mathrm{H}, \mathrm{H}}=5.4 \mathrm{~Hz}, 2.6,2.6,1 \mathrm{H}\right)$, $4.13\left(\mathrm{dd}, J_{\mathrm{H}, \mathrm{H}}=5.3,2.7 \mathrm{~Hz}, 1 \mathrm{H}\right), 3.99\left(\mathrm{dd}, J_{\mathrm{H}, \mathrm{H}}=11.7,2.7 \mathrm{~Hz}, 1 \mathrm{H}\right), 3.87$ (dd, $J_{H, H}=11.7,2.8 \mathrm{~Hz}, 1 \mathrm{H}$ ), 2.76 (ddd, $J_{\mathrm{H}, \mathrm{H}}=13.2,8.2,5.5 \mathrm{~Hz}, 1 \mathrm{H}$ ), 2.35 (ddd, $\left.J_{H, H}=13.0,5.4,2.5 \mathrm{~Hz}, 1 \mathrm{H}\right), 0.93(\mathrm{~s}, 9 \mathrm{H}), 0.79(\mathrm{~s}, 9 \mathrm{H}), 0.13$ $(\mathrm{s}, 3 \mathrm{H}), 0.12(\mathrm{~s}, 3 \mathrm{H}),-0.02(\mathrm{~s}, 3 \mathrm{H}),-0.04 \mathrm{ppm}(\mathrm{s}, 3 \mathrm{H}) ;{ }^{13} \mathrm{C}$ NMR (101 $\mathrm{MHz}_{1} \mathrm{CDCl}_{3}$ ): $\delta=151.3,149.9,149.2,139.0,129.2,123.4,120.1$, $119.8,116.2,88.7,85.5,72.1,63.0,40.2,26.1,25.9,17.8,17.7,-4.4$, $-4.6,-5.1,-5.2 \mathrm{ppm}$; IR (ATR): $\vec{v}=3331,3184,2952,2928,2885$, $2856,1742,1636,1599,1557,1498,1471,1450,1346,1282,1251$, $1108,1058,1028,1006,951,883,831,775,747,690,668,577,538$, 521, $498 \mathrm{~cm}^{-1}$; HRMS $\left(\left.E S\right|^{+}\right): \mathrm{m} / z$ calcd: $570.3170[M]^{+}$; found: $571.3254[\mathrm{M}+\mathrm{H}]^{+}, 593.3066[\mathrm{M}+\mathrm{Na}]^{+}, 609.2817[\mathrm{M}+\mathrm{K}]^{+}$.

8-N-3,5-Dimethylphenyl-3',5'-O-bis(tert-butyldimethylsilyl)-2'-deoxyadenosine (12 b): GP-I was conducted with 11 (3.00 g, $5.38 \mathrm{mmol}$ ) and 3,5-dimethylaniline, which afforded the desired product as a pale yellow foam $(2.35 \mathrm{~g}, 3.93 \mathrm{mmol}, 73 \%)$. M.p. $68^{\circ} \mathrm{C} ;[\alpha]_{589 \mathrm{~nm}}^{20}=5\left(c=0.25, \mathrm{CHCl}_{3}\right) ;{ }^{1} \mathrm{H}$ NMR $\left(400 \mathrm{MHz}_{,} \mathrm{CDCl}_{3}\right): \delta=$ 8.15 (s, $1 \mathrm{H}), 7.90$ (brs, $1 \mathrm{H}), 7.08$ (s, 2H), 6.86 (brs, 2H), $8.78(\mathrm{~s}, 1 \mathrm{H})$, $6.44\left(\mathrm{dd}, J_{\mathrm{H}, \mathrm{H}}=5.4,8.4 \mathrm{~Hz}, 1 \mathrm{H}\right), 4.55\left(\mathrm{dt}, J_{\mathrm{H}, \mathrm{H}}=2.7,5.6 \mathrm{~Hz}, 1 \mathrm{H}\right), 4.09$ (dd, $J_{H, H}=2.9,5.7 \mathrm{~Hz}, 1 \mathrm{H}$ ), 3.97 (dd, $\left.J_{H, H}=11.6,3.1 \mathrm{~Hz}, 1 \mathrm{H}\right), 3.85$ (dd, $J_{\mathrm{H}, \mathrm{H}}=11.6,3.0 \mathrm{~Hz}, 1 \mathrm{H}$ ), 2.78 (ddd, $\left.J_{\mathrm{H}, \mathrm{H}}=13.0,8.4,5.9 \mathrm{~Hz}, 1 \mathrm{H}\right), 2.36-$ $2.27(\mathrm{~m}, 1 \mathrm{H}), 2.32(\mathrm{~s}, 6 \mathrm{H}), 0.93(\mathrm{~s}, 9 \mathrm{H}), 0.79(\mathrm{~s}, 9 \mathrm{H}), 0.13(\mathrm{~s}, 3 \mathrm{H})$, 
$0.11(s, 3 \mathrm{H}),-0.03(\mathrm{~s}, 3 \mathrm{H}),-0.04 \mathrm{ppm}(\mathrm{s}, 3 \mathrm{H}) ;{ }^{13} \mathrm{C}$ NMR $(101 \mathrm{MHz}$, $\left.\mathrm{CDCl}_{3}\right): \delta=150.1,149.9,149.0,140.0,139.1,129.0,119.2,119.0$, $118.7,88.4,85.1,72.2,62.4,39.8,26.0,25.9,21.6,17.8,17.7,-4.6$ $-5.7 \mathrm{ppm} ;$ IR (ATR): $\tilde{v}=3451,3332,3186,2953,2927,2856,1647$ $1615,1595,1567,1545,1462,1333,1290,1253,1184,1109,1072$ 1026, 1006, 971, 945, 871, 831, 775, 718, 686, 665, 574, 540, 504, $403 \mathrm{~cm}^{-1}$; HRMS (FAB): $\mathrm{m} / z$ calcd: $598.3483\left[\mathrm{M}^{+}\right.$; found: 599.3562 $[\mathrm{M}+\mathrm{H}]^{+}$.

8-N-4-Methoxyphenyl-3',5'-O-bis(tert-butyldimethylsilyl)-2'-deoxyadenosine (12 c): GP-I was conducted with $11(4.00 \mathrm{~g}, 7.16 \mathrm{mmol})$ and 4-methoxyaniline, which afforded the desired product as a pale yellow foam $(3.86 \mathrm{~g}, 6.42 \mathrm{mmol}, 90 \%)$. M.p. $87^{\circ} \mathrm{C} ;[\alpha]_{589 \mathrm{~mm}}^{22}=$ $21.0\left(c=0.5, \mathrm{CH}_{3} \mathrm{Cl}\right) ;{ }^{1} \mathrm{H} \mathrm{NMR}\left(400 \mathrm{MHz}_{1} \mathrm{CDCl}_{3}\right): \delta=8.15(\mathrm{~s}, 1 \mathrm{H})$, 7.84 (brs, $1 \mathrm{H}), 7.42-7.36(\mathrm{~m}, 2 \mathrm{H}), 6.93-6.86(\mathrm{~m}, 2 \mathrm{H}), 6.47\left(\mathrm{dd}, J_{\mathrm{H}, \mathrm{H}}=\right.$ $8.6,5.5 \mathrm{~Hz}, 1 \mathrm{H}), 6.45(\mathrm{brs}, 2 \mathrm{H}), 4.58-4.52(\mathrm{~m}, 1 \mathrm{H}), 4.08\left(\mathrm{dd}, J_{\mathrm{H}, \mathrm{H}}=\right.$ $5.3,2.7 \mathrm{~Hz}, 1 \mathrm{H}), 3.99\left(\mathrm{dd}, J_{\mathrm{H}, \mathrm{H}}=11.6,2.7 \mathrm{~Hz}, 1 \mathrm{H}\right), 3.85\left(\mathrm{dd}, J_{\mathrm{H}, \mathrm{H}}=\right.$ $11.7,42.8 \mathrm{~Hz}, 1 \mathrm{H}$ ), 2.76 (ddd, $J_{\mathrm{H}, \mathrm{H}}=13.0,8.6,6.0 \mathrm{~Hz}, 1 \mathrm{H}$ ), 2.30 (ddd, $\left.J_{\mathrm{H}, \mathrm{H}}=13.0,5.5,2.4 \mathrm{~Hz}, 1 \mathrm{H}\right), 0.93(\mathrm{~s}, 9 \mathrm{H}), 0.79(\mathrm{~s}, 9 \mathrm{H}), 0.13(\mathrm{~s}, 3 \mathrm{H})$ $0.11(\mathrm{~s}, 3 \mathrm{H}),-0.03(\mathrm{~s}, 3 \mathrm{H}),-0.06 \mathrm{ppm}(\mathrm{s}, 3 \mathrm{H}) ;{ }^{13} \mathrm{C}$ NMR $(101 \mathrm{MHz}$, $\left.\mathrm{CDCl}_{3}\right): \delta=156.9,150.8,150.0,149.6,131.4,123.8,123.8,116.8$, $114.5,88.3,84.9,72.2,63.1,55.7,39.8,26.1,25.9,18.8,18.2,-4.4$, $-4.6,-5.2,-5.2 \mathrm{ppm}$; IR (ATR): $\ddot{v}=3332,3179,2952,2928,2856$, $1637,1604,1561,1509,1463,1440,1419,1390,1340,1285,1245$ $1180,1107,1059,1033,1006,970,951,938,883,827,775,719$, $668,577,536,505,459 \mathrm{~cm}^{-1}$; MS (FAB): $\mathrm{m} / \mathrm{z}$ calcd: $600.32[\mathrm{M}]^{+}$; found: $601.33[\mathrm{M}+\mathrm{H}]^{+}$.

8-N-4-Biphenyl-3',5'-O-bis(tert-butyldimethylsilyl)-2'-deoxyadenosine (12 d): GP-I was conducted with $11(3.00 \mathrm{~g}, 5.38 \mathrm{mmol})$ and 4-biphenylamine, which afforded the desired product as a pale yellow foam $(2.85 \mathrm{~g}, 4.41 \mathrm{mmol}, 82 \%)$. M.p. $85^{\circ} \mathrm{C} ;[\alpha]_{589 \mathrm{~nm}}^{20}=33.6$ $\left(c=1.1, \mathrm{CHCl}_{3}\right) ;{ }^{1} \mathrm{H}$ NMR $\left(400 \mathrm{MHz}, \mathrm{CDCl}_{3}\right): \delta=8.18(\mathrm{~s}, 1 \mathrm{H}), 8.07$ (brs, 1H), 7.65-7.61 (m, 2H), 7.61-7.56 (m, 4H), 7.47-7.41 (m, 2H), 7.36-7.30 (m, 1 H), 6.46 (dd, $\left.J_{\mathrm{H}, \mathrm{H}}=8.3,5.5 \mathrm{~Hz}, 1 \mathrm{H}\right), 6.44(\mathrm{brs}, 2 \mathrm{H})$, $4.57\left(\mathrm{dt}, J_{\mathrm{H}, \mathrm{H}}=5.7,2.8 \mathrm{~Hz}, 1 \mathrm{H}\right), 4.11\left(\mathrm{dd}, J_{\mathrm{H}, \mathrm{H}}=5.8,2.9 \mathrm{~Hz}, 1 \mathrm{H}\right), 4.00$ $\left(\mathrm{dd}, J_{\mathrm{H}, \mathrm{H}}=11.6,3.0 \mathrm{~Hz}, 1 \mathrm{H}\right), 3.87\left(\mathrm{dd}, J_{\mathrm{H}, \mathrm{H}}=11.6,3.1 \mathrm{~Hz}, 1 \mathrm{H}\right), 2.82$ (ddd, $J_{\mathrm{H}, \mathrm{H}}=13.1,8.1,5.9 \mathrm{~Hz}, 1 \mathrm{H}$ ), 2.35 (ddd, $J_{\mathrm{H}, \mathrm{H}}=13.0,5.5,2.7 \mathrm{~Hz}$ $1 \mathrm{H}), 0.93(\mathrm{~s}, 9 \mathrm{H}), 0.82(\mathrm{~s}, 9 \mathrm{H}), 0.13(\mathrm{~s}, 3 \mathrm{H}), 0.12(\mathrm{~s}, 3 \mathrm{H}), 0.02(\mathrm{~s}, 3 \mathrm{H})$, $0.00 \mathrm{ppm}(\mathrm{s}, 3 \mathrm{H}) ;{ }^{13} \mathrm{C}$ NMR $\left(101 \mathrm{MHz}, \mathrm{CDCl}_{3}\right): \delta=150.0,149.7$, $149.0,140.7,138.0,136.7,129.0,127.8,127.0,127.2,126.9,120.7$, 117.3, 88.4, 85.3, 72.1, 63.0, 40.0, 26.1, 25.9, 18.7, 18.2, -4.4, -4.6, $-5.1,-5.2 \mathrm{ppm}$; IR (ATR): $\vec{v}=3345,2952,2927,2884,2856,1636$, $1598,1575,1551,1487,1470,1449,1411,1339,1288,1252,1108$, $1058,1025,1006,951,876,831,776,760,717,696,667,577,548$, $499 \mathrm{~cm}^{-1}$; HRMS (FAB): $\mathrm{m} / \mathrm{z}$ calcd: $646.3483\left[\mathrm{M}^{+}\right.$; found: 647.3554 $[\mathrm{M}+\mathrm{H}]^{+}$.

General Procedure II (GP-II) for the $\mathrm{N}^{6}$-dibenzoylation of the 8-Narylamine-2'-dA adducts to afford compounds $13 \mathrm{a}-\mathrm{d}$ : The appropriate compound 12 was dissolved in anhydrous pyridine $(30 \mathrm{~mL})$ under nitrogen and benzoyl chloride (5 equiv) was added. The reaction mixture was stirred until the reaction was complete (12-16 h). It was then diluted with $\mathrm{CH}_{2} \mathrm{Cl}_{2}(50 \mathrm{~mL})$ and washed with saturated sodium hydrogencarbonate solution, and the aqueous layer was extracted twice with $\mathrm{CH}_{2} \mathrm{Cl}_{2}$. The organic layer was dried over sodium sulfate and the solvent was removed in vacuo and coevaporation with toluene was performed three times. Purification of the residue by flash chromatography on silica gel, with elution with $\mathrm{MeOH}$ in $\mathrm{CH}_{2} \mathrm{Cl}_{2}(0 \rightarrow 1 \%)$, gave the product 13 .

$N^{6}$-Dibenzoyl-8- $N$-(phenyl)-3',5'-O-bis(tert-butyldimethylsilyl)-2'deoxyadenosine (13a): GP-II was conducted with $12 \mathrm{a}(2.34 \mathrm{~g}$, $4.09 \mathrm{mmol})$, which afforded the product as a yellow foam $(2.82 \mathrm{~g}$, $3.62 \mathrm{mmol}, 85 \%)$. M.p. $96^{\circ} \mathrm{C} ;[\alpha]_{589 \mathrm{~nm}}^{20}=29.2\left(\mathrm{c}=0.5, \mathrm{CHCl}_{3}\right) ;{ }^{1} \mathrm{H}$ NMR
(400 MHz, $\left.\mathrm{CDCl}_{3}\right): \delta=8.59(\mathrm{~s}, 1 \mathrm{H}), 7.68-7.63(\mathrm{~m}, 3 \mathrm{H}), 7.52-7.48(\mathrm{~m}$, $2 \mathrm{H}), 7.48-7.38(\mathrm{~m}, 3 \mathrm{H}), 7.40-7.32(\mathrm{~m}, 2 \mathrm{H}), 7.31-7.26(\mathrm{~m}, 4 \mathrm{H}), 7.20-$ $7.16(\mathrm{~m}, 2 \mathrm{H}), 6.16\left(\mathrm{dd}, J_{\mathrm{H}, \mathrm{H}}=6.2,7.9 \mathrm{~Hz}, 1 \mathrm{H}\right), 4.64-4.56(\mathrm{~m}, 1 \mathrm{H})$, $3.97-3.88(\mathrm{~m}, 2 \mathrm{H}), 3.73\left(\mathrm{dd}, J_{\mathrm{H}, \mathrm{H}}=9.0,3.7 \mathrm{~Hz}, 1 \mathrm{H}\right), 3.15-3.06(\mathrm{~m}$, $1 \mathrm{H}), 1.75-1.60(\mathrm{~m}, 1 \mathrm{H}), 0.86(\mathrm{~s}, 9 \mathrm{H}), 0.85(\mathrm{~s}, 9 \mathrm{H}), 0.06(\mathrm{~s}, 3 \mathrm{H}), 0.02$ $(\mathrm{s}, 3 \mathrm{H}), 0.01(\mathrm{~s}, 3 \mathrm{H}),-0.01 \mathrm{ppm}(\mathrm{s}, 3 \mathrm{H}) ;{ }^{13} \mathrm{C}$ NMR $\left(101 \mathrm{MHz}, \mathrm{CDCl}_{3}\right)$ : $\delta=172.2,152.0,150.5,149.0,139.5,134.5,132.7,131.5,129.7$, 129.4, 128.8, 128.7, 128.4, 127.7, 119.0, 118.7, 88.4, 85.3, 72.7, 63.2, $36.7,26.0,25.9,17.8,17.7,-4.6,-5.2 \mathrm{ppm}$; IR (ATR): $\tilde{\nu}=2952$, $2928,2885,2855,1699,1600,1575,1515,1491,1471,1448,1404$, $1350,1278,1238,1177,1070,1026,1003,984,933,909,834,775$, 753, 715, 692,617, 602, 579, $506 \mathrm{~cm}^{-1}$; HRMS $\left(\mathrm{ESI}^{+}\right): \mathrm{m} / \mathrm{z}$ calcd: $778.3694[\mathrm{M}]^{+}$; found: $779.3771[\mathrm{M}+\mathrm{H}]^{+}, 801.3584[\mathrm{M}+\mathrm{Na}]^{+}$, $817.3311[\mathrm{M}+\mathrm{K}]^{+}$.

$N^{6}$-Dibenzoyl-8- $N$-(3,5-dimethylphenyl)-3',5'-O-bis(tert-butyldimethylsilyl)-2'-deoxyadenosine (13b): GP-II was conducted with $12 \mathrm{~b}(2.34 \mathrm{~g}, 3.91 \mathrm{mmol})$, which afforded the product as a yellow foam $(2.81 \mathrm{~g}, 3.49 \mathrm{mmol}, 89 \%)$. M.p. $90^{\circ} \mathrm{C} ;[\alpha]_{589 \mathrm{~nm}}^{20}=160.6(c=0.5$, $\left.\mathrm{CHCl}_{3}\right)$; ' $\mathrm{HNMR}\left(400 \mathrm{MHz}, \mathrm{CDCl}_{3}\right): \delta=8.58(\mathrm{~s}, 1 \mathrm{H}), 8.12-8.08(\mathrm{~m}$, 1H), 7.65-7.62 (m, 4H), 7.50-7.36 (m, 6H), $6.91(\mathrm{~s}, 1 \mathrm{H}), 6.80(\mathrm{~s}, 2 \mathrm{H})$, $6.13\left(\mathrm{dd}, J_{\mathrm{H}, \mathrm{H}}=6.3,7.8 \mathrm{~Hz}, 1 \mathrm{H}\right), 4.65-4.60(\mathrm{~m}, 1 \mathrm{H}), 3.96-3.90(\mathrm{~m}$, $2 \mathrm{H}$ ), $3.87\left(\mathrm{dd}, J_{\mathrm{H}, \mathrm{H}}=13.9,8.6 \mathrm{~Hz}, 1 \mathrm{H}\right.$ ), 3.10 (ddd, $J_{\mathrm{H}, \mathrm{H}}=13.2,7.6$, $5.6 \mathrm{~Hz}, 1 \mathrm{H}), 2.26(\mathrm{~s}, 6 \mathrm{H}), 1.76-1.68(\mathrm{~m}, 1 \mathrm{H}), 0.87(\mathrm{~s}, 9 \mathrm{H}), 0.85(\mathrm{~s}$, $9 \mathrm{H}), 0.07(\mathrm{~s}, 3 \mathrm{H}), 0.03(\mathrm{~s}, 3 \mathrm{H}), 0.02(\mathrm{~s}, 3 \mathrm{H}),-0.01 \mathrm{ppm}(\mathrm{s}, 3 \mathrm{H})$; ${ }^{13} \mathrm{C}$ NMR $\left(101 \mathrm{MHz}, \mathrm{CDCl}_{3}\right): \delta=172.2,152.0,150.5,149.0,140.0$, $139.4,134.5,132.7,131.4,130.3,129.8,128.7,128.3,124.2,119.0$, $118.7,88.5,85.1,72.8,63.5,36.4,26.1,25.9,21.2,17.8,17.7,-4.6$, $-4.8 \mathrm{ppm}$; IR (ATR): $\tilde{v}=2952,2928,2884,2856,1700,1599,1575$, $1515,1471,1462,1449,1404,1350,1302,1278,1238,1176,1072$, $1027,1003,984,936,909,867,832,798,775,713,693,635,615$, 580, 548, 513, $406 \mathrm{~cm}^{-1}$; HRMS $\left(\mathrm{ESI}^{+}\right): \mathrm{m} / \mathrm{z}$ calcd: $806.4007\left[\mathrm{M}^{+}\right.$; found: $807.4090[\mathrm{M}+\mathrm{H}]^{+}$.

$\mathrm{N}^{6}$-Dibenzoyl-8- $\mathrm{N}$-(4-methoxyphenyl)-3',5'-O-bis(tert-butyldimethylsilyl)-2'-deoxyadenosine (13c): GP-\|l was conducted with $12 \mathrm{c}(3.84 \mathrm{~g}, 6.38 \mathrm{mmol})$, which afforded the product as a yellow foam $(5.06 \mathrm{~g}, 6.25 \mathrm{mmol}, 98 \%)$. M.p. $79^{\circ} \mathrm{C} ;[\alpha]_{589 \mathrm{~nm}}^{20}=167.8(c=0.5$, $\left.\mathrm{CHCl}_{3}\right)$; 'H NMR $\left(400 \mathrm{MHz}, \mathrm{CDCl}_{3}\right): \delta=8.59(\mathrm{~s}, 1 \mathrm{H}), 8.13-8.09(\mathrm{~m}$, $1 \mathrm{H}), 7.69-7.64(\mathrm{~m}, 4 \mathrm{H}), 7.51-7.37(\mathrm{~m}, 6 \mathrm{H}), 7.13\left(\mathrm{~d}, J_{\mathrm{H}, \mathrm{H}}=8.8 \mathrm{~Hz}\right.$, $2 \mathrm{H}), 6.84\left(\mathrm{~d}, J_{\mathrm{H}, \mathrm{H}}=9.0 \mathrm{~Hz}, 2 \mathrm{H}\right), 6.18\left(\mathrm{dd}, J_{\mathrm{H}, \mathrm{H}}=6.6,7.5 \mathrm{~Hz}, 1 \mathrm{H}\right), 4.66-$ $4.58(\mathrm{~m}, 1 \mathrm{H}), 3.98-3.88(\mathrm{~m}, 2 \mathrm{H}), 3.80(\mathrm{~s}, 3 \mathrm{H}), 3.73\left(\mathrm{dd}, J_{\mathrm{H}, \mathrm{H}}=9.6\right.$, $4.2 \mathrm{~Hz}, 1 \mathrm{H}), 3.18-3.06(\mathrm{~m}, 1 \mathrm{H}), 1.82-1.62(\mathrm{~m}, 1 \mathrm{H}), 0.86(\mathrm{~s}, 9 \mathrm{H}), 0.85$ $(\mathrm{s}, 9 \mathrm{H}), 0.07(\mathrm{~s}, 3 \mathrm{H}), 0.03(\mathrm{~s}, 3 \mathrm{H}), 0.01(\mathrm{~s}, 3 \mathrm{H}),-0.01 \mathrm{ppm}(\mathrm{s}, 3 \mathrm{H})$; ${ }^{13} \mathrm{C}$ NMR $\left(101 \mathrm{MHz}, \mathrm{CDCl}_{3}\right): \delta=172.2,156.9,152.8,151.5,149.6$, 134.5, 132.7, 130.9, 130.3, 129.4, 128.7, 128.6, 128.3, 123.8, 119.0, $118.7,114.9,88.4,85.3,72.8,63.3,55.6,36.7,26.1,25.9,18.3,17.6$, $-4.4,-4.6,-5.2,-5.2 \mathrm{ppm}$; IR (ATR): $\vec{v}=2952,2928,2884,2855$, $1694,1601,1575,1509,1449,1351,1280,1246,1175,1108,1092$, $1071,1026,984,934,910,866,832,775,693,664,641,606,580$, 549, $528 \mathrm{~cm}^{-1}$; HRMS (FAB): $\mathrm{m} / \mathrm{z}$ calcd: $808.3800\left[\mathrm{M}^{+}{ }^{+}\right.$; found: $809.3813[\mathrm{M}+\mathrm{H}]^{+}$.

$N^{6}$-Dibenzoyl-8-N-(4-biphenyl)-3', 5'-O-bis(tert-butyldimethylsilyl)2'-deoxyadenosine (13 d): GP-II was conducted with $12 \mathrm{~d}(2.84 \mathrm{~g}$, $4.39 \mathrm{mmol})$, which afforded the product as a yellow foam $(3.40 \mathrm{~g}$, $3.98 \mathrm{mmol}, 91 \%)$. M.p. $122{ }^{\circ} \mathrm{C} ;[\alpha]_{589 \mathrm{~nm}}^{20}=172.2\left(c=0.5, \quad \mathrm{CHCl}_{3}\right)$; ' $\mathrm{H}$ NMR $\left(400 \mathrm{MHz}, \mathrm{CDCl}_{3}\right): \delta=8.60(\mathrm{~s}, 1 \mathrm{H}), 7.59-7.50(\mathrm{~m}, 6 \mathrm{H}), 7.49-$ $7.41(\mathrm{~m}, 5 \mathrm{H}), 7.39-7.34(\mathrm{~m}, 1 \mathrm{H}), 7.32-7.21(\mathrm{~m}, 8 \mathrm{H}), 6.19\left(\mathrm{dd}, J_{\mathrm{HH}}=\right.$ $6.7,7.5 \mathrm{~Hz}, 1 \mathrm{H}), 4.68-4.58(\mathrm{~m}, 1 \mathrm{H}), 3.99-3.87(\mathrm{~m}, 2 \mathrm{H}), 3.74$ (dd, $\left.J_{H, H}=9.4,4.0 \mathrm{~Hz}, 1 \mathrm{H}\right), 3.19-3.08(\mathrm{~m}, 1 \mathrm{H}), 1.80-1.64(\mathrm{~m}, 1 \mathrm{H}), 0.86(\mathrm{~s}$, $9 \mathrm{H}), 0.83(\mathrm{~s}, 9 \mathrm{H}), 0.07(\mathrm{~s}, 3 \mathrm{H}), 0.06(\mathrm{~s}, 3 \mathrm{H}), 0.01(\mathrm{~s}, 3 \mathrm{H}),-0.01 \mathrm{ppm}$ $(\mathrm{s}, 3 \mathrm{H}) ;{ }^{13} \mathrm{C} \mathrm{NMR}\left(101 \mathrm{MHz}, \mathrm{CDCl}_{3}\right): \delta=172.2,152.6,151.8,150.3$, $140.6,140.1,139.4,134.5,132.8,131.6,129.8,129.0,128.8,128.7$, 128.4, 128., 127.9, 127.2, 119.0, 88.4, 85.3, 72.7, 63.2, 36.7, 26.1, 
25.9, 17.8, 17.7, -4.6, $-5.2 \mathrm{ppm}$; IR (ATR): $\tilde{\nu}=2952,2927,2855$ $1700,1600,1575,1517,1486,1471,1448,1348,1278,1248,1178$, 1072, 1026, 1007, 984, 932, 910, 832, 775, 763, 720, 693, 667, 642, $604,568,553,503,411 \mathrm{~cm}^{-1}$; MS (FAB): $\mathrm{m} / z$ calcd: $854.4007\left[\mathrm{M}^{+}\right.$; found: $856.4056[\mathrm{M}+2 \mathrm{H}]^{+}$.

General Procedure III for the 8-N-acetyation of the $N^{6}-(B z)_{2}$-arylamine-2'-dA adducts to afford compounds $14 \mathrm{a}-\mathrm{d}$ : The appropriate compound 13 and 4-DMAP (3 equiv) were dissolved in anhydrous pyridine $\left(30 \mathrm{~mL}\right.$ ) under nitrogen and $\mathrm{Ac}_{2} \mathrm{O}$ (3 equiv) was added. The reaction mixture was stirred until the reaction was complete (30-72 h). It was then diluted with dichloromethane $(50 \mathrm{~mL})$ and washed with saturated sodium hydrogencarbonate solution, and the aqueous layer was extracted twice with dichloromethane. The organic layer was dried over sodium sulfate and the solvent was removed in vacuo. Coevaporation three times with toluene followed. Purification of the residue by flash chromatography on silica gel, with elution with methanol in dichloromethane $(0 \rightarrow$ $0.5 \%)$, gave the desired product.

$N^{6}$-Benzoyl-8-( $N$-acetyl)-phenyl-3', 5'-O-bis(tert-butyldimethylsilyl)-2'-deoxyadenosine (14a): GP-III was conducted with 13 a $(0.71 \mathrm{~g}, 0.92 \mathrm{mmol})$, which afforded the desired product as a yellow foam $(0.63 \mathrm{~g}, 0.88 \mathrm{mmol}, 81 \%)$. M.p. $87^{\circ} \mathrm{C} ;[\alpha]_{589 \mathrm{~nm}}^{25}=12.8$ $\left(c=0.5, \mathrm{CHCl}_{3}\right) ;{ }^{1} \mathrm{HNMR}\left(400 \mathrm{MHz} \mathrm{CDCl}_{3}\right): \delta=8.63(\mathrm{~s}, 1 \mathrm{H}), 7.60$ $7.55(\mathrm{~m}, 2 \mathrm{H}), 7.49-7.44(\mathrm{~m}, 1 \mathrm{H}), 7.43-7.37(\mathrm{~m}, 1 \mathrm{H}), 7.35-7.30(\mathrm{~m}$, $2 \mathrm{H}), 7.30-7.23(\mathrm{~m}, 4 \mathrm{H}), 6.23\left(\mathrm{t}, J_{\mathrm{H}, \mathrm{H}}=6.9 \mathrm{~Hz}, 1 \mathrm{H}\right), 4.76-4.68(\mathrm{~m}, 1 \mathrm{H})$, 4.01-3.93 (m, 2H), $3.72\left(\mathrm{dd}, J_{\mathrm{H}, \mathrm{H}}=14.2,8.5 \mathrm{~Hz}, 1 \mathrm{H}\right), 3.42-3.28(\mathrm{~m}$, $1 \mathrm{H}), 2.53(\mathrm{~s}, 3 \mathrm{H}), 1.97-1.81(\mathrm{~m}, 1 \mathrm{H}), 0.84(\mathrm{~s}, 9 \mathrm{H}), 0.83(\mathrm{~s}, 9 \mathrm{H}), 0.09$ $(\mathrm{s}, 3 \mathrm{H}), 0.04(\mathrm{~s}, 3 \mathrm{H}), 0.02(\mathrm{~s}, 3 \mathrm{H}), 0.01 \mathrm{ppm}(\mathrm{s}, 3 \mathrm{H}) ;{ }^{13} \mathrm{C} N M R$ $\left(101 \mathrm{MHz} \mathrm{CDCl}_{3}\right): \delta=172.2,168.7,152.0,150.5,149.0,139.5,134.5$, $132.7,131.5,129.7,129.4,128.8,128.7,128.4,127.7,119.0,118.7$, $88.4,85.3,72.7,63.2,36.7,26.0,25.9,24.3,17.8,17.7,-4.6$ -5.2 ppm; IR (ATR): $\tilde{v}=2952,2928,2885,2856,1682,1609,1582$ $1524,1493,1471,1462,1406,1354,1279,1250,1176,1009,1066$, $1029,1004,948,833,775,752,712,693,669,617,597,573,548$, $504 \mathrm{~cm}^{-1}$; HRMS $\left(\mathrm{ESI}^{+}\right.$): $\mathrm{m} / \mathrm{z}$ calcd: $716.3538[\mathrm{M}]^{+}$; found: 717.3611 $[\mathrm{M}+\mathrm{H}]^{+}$.

$N^{6}$-Benzoyl-8-( $N$-acetyl)-3,5-dimethylphenyl-3',5'-O-bis(tert-butyldimethylsilyl)-2'-deoxyadenosine (14b): GP-III was conducted with $13 \mathrm{~b}(2.79 \mathrm{~g}, 3.46 \mathrm{mmol})$, which afforded the desired product as a yellow foam $(1.10 \mathrm{~g}, 1.48 \mathrm{mmol}, 43 \%)$. M.p. $82^{\circ} \mathrm{C} ;[\alpha]_{589 \mathrm{~nm}}^{25}=$ $269.6\left(c=0.5, \mathrm{CHCl}_{3}\right) ;{ }^{1} \mathrm{H}$ NMR (400 MHz, [D $]$ DMSO): $\delta=10.68$ (s, $1 \mathrm{H}), 8.61(\mathrm{~s}, 1 \mathrm{H}), 7.64-7.59(\mathrm{~m}, 1 \mathrm{H}), 7.49-7.44(\mathrm{~m}, 2 \mathrm{H}), 7.36-7.32$ $(\mathrm{m}, 2 \mathrm{H}), 6.93(\mathrm{~s}, 1 \mathrm{H}), 6.88(\mathrm{~s}, 2 \mathrm{H}), 6.21\left(\mathrm{t}, J_{\mathrm{H}, \mathrm{H}}=6.5 \mathrm{~Hz}, 1 \mathrm{H}\right), 4.90-$ $4.56(\mathrm{~m}, 1 \mathrm{H}), 3.95-3.83(\mathrm{~m}, 2 \mathrm{H}), 3.74-3.68(\mathrm{~m}, 1 \mathrm{H}), 3.22-3.03(\mathrm{~m}$, $1 \mathrm{H}), 2.19(\mathrm{~s}, 6 \mathrm{H}), 2.16(\mathrm{~s}, 3 \mathrm{H}), 1.97-1.81(\mathrm{~m}, 1 \mathrm{H}), 0.82(\mathrm{~s}, 9 \mathrm{H}), 0.80$ $(\mathrm{s}, 9 \mathrm{H}), 0.07(\mathrm{~s}, 3 \mathrm{H}), 0.05(\mathrm{~s}, 3 \mathrm{H}), 0.03(\mathrm{~s}, 3 \mathrm{H}), 0.01 \mathrm{ppm}(\mathrm{s}, 3 \mathrm{H})$; ${ }^{13} \mathrm{C}$ NMR $\left(101 \mathrm{MHz} \mathrm{CDCl}_{3}\right): \delta=172.2,168.7,150.8,150.1,149.4$, $140.3,138.7,131.6,131.5,128.9,128.5,128.4,128.2,127.7,119.0$, $118.7,88.4,84.9,70.9,61.9,38.9,26.0,25.9,24.3,20.6,17.8,17.7$ $-4.6,-5.2 \mathrm{ppm}$; IR (ATR): $\tilde{v}=2952,2928,2855,1691,1609,1583$, $1525,1462,1407,1353,1281,1251,1176,1110,1066,1029,1005$, 939, 834, 775, 710,669, 611, 571, $543 \mathrm{~cm}^{-1}$; HRMS $\left.(E S)^{+}\right): \mathrm{m} / \mathrm{z}$ calcd: $744.3851[M]^{+}$; found: $745.3926[\mathrm{M}+\mathrm{H}]^{+}$.

$N^{6}$-Benzoyl-8-( $N$-acetyl)-4-methoxyphenyl-3', $5^{\prime}$-O-bis(tert-butyldimethylsilyl)-2'-deoxyadenosine (14c): GP-III was conducted with $13 \mathrm{c}(1.01 \mathrm{~g}, 1.17 \mathrm{mmol})$, which afforded the desired product as a yellow foam $(1.03 \mathrm{~g}, 1.29 \mathrm{mmol}, 81 \%)$. M.p. $95^{\circ} \mathrm{C} ;[\alpha]_{589 \mathrm{~nm}}^{25}=34.4$ $\left(c=0.5, \mathrm{CHCl}_{3}\right) ;{ }^{1} \mathrm{H}$ NMR $\left(400 \mathrm{MHz}_{1} \mathrm{CDCl}_{3}\right): \delta=8.63(\mathrm{~s}, 1 \mathrm{H}), 7.54(\mathrm{~d}$, $\left.J_{\mathrm{H}, \mathrm{H}}=6.7 \mathrm{~Hz}, 2 \mathrm{H}\right), 7.45\left(\mathrm{t}, J_{\mathrm{H}, \mathrm{H}}=7.4 \mathrm{~Hz}, 1 \mathrm{H}\right), 7.36\left(\mathrm{t}, J_{\mathrm{H}, \mathrm{H}}=7.6 \mathrm{~Hz}, 2 \mathrm{H}\right)$, $7.25\left(\mathrm{~d}, J_{\mathrm{H}, \mathrm{H}}=8.8 \mathrm{~Hz}, 2 \mathrm{H}\right), 6.94\left(\mathrm{~d}, J_{\mathrm{H}, \mathrm{H}}=8.4 \mathrm{~Hz}, 2 \mathrm{H}\right), 6.33\left(\mathrm{dd}, J_{\mathrm{H}, \mathrm{H}}=\right.$ $7.0,6.9 \mathrm{~Hz}, 1 \mathrm{H}), 4.55-4.46(\mathrm{~m}, 1 \mathrm{H}), 3.92\left(\mathrm{dd}, J_{\mathrm{H}, \mathrm{H}}=7.7,4.7 \mathrm{~Hz}, 1 \mathrm{H}\right)$, $3.73(\mathrm{~s}, 3 \mathrm{H}), 3.74-3.69(\mathrm{~m}, 1 \mathrm{H}), 3.57$ (ddd, $J_{\mathrm{H}, \mathrm{H}}=11.7,5.9,4.8 \mathrm{~Hz}$, $1 \mathrm{H}), 3.06-2.93(\mathrm{~m}, 1 \mathrm{H}), 2.20(\mathrm{~s}, 3 \mathrm{H}), 2.02-1.91(\mathrm{~m}, 1 \mathrm{H}), 0.87(\mathrm{~s}, 9 \mathrm{H})$, $0.85(\mathrm{~s}, 9 \mathrm{H}), 0.07(\mathrm{~s}, 3 \mathrm{H}), 0.03(\mathrm{~s}, 3 \mathrm{H}), 0.02(\mathrm{~s}, 3 \mathrm{H}),-0.01 \mathrm{ppm}(\mathrm{s}$, $3 \mathrm{H}) ;{ }^{13} \mathrm{CNMR}\left(101 \mathrm{MHz}, \mathrm{CDCl}_{3}\right): \delta=172.1,168.6,151.4,150.7$, $149.3,147.5,139.4,134.5,133.8,133.5,133.0,131.3,128.3,128.1$, $127.8,121.7,114.6,88.3,84.8,70.8,61.8,55.2,37.1,26.1,25.9,24.1$, $17.8,17.7,-4.6,-4.8 \mathrm{ppm}$; IR (ATR): $\tilde{v}=2953,2929,2885,2856$, $2165,2054,2037,2018,1983,1951,1747,1679,1610,1583,1528$, $1509,1462,1408,1374,1356,1319,1283,1246,1182,1108,1065$, $1031,1000,950,891,831,803,774,719,692,661,608,580,550$, $526 \mathrm{~cm}^{-1}$; HRMS $\left(E S I^{+}\right): \mathrm{m} / \mathrm{z}$ calcd: $746.3634\left[\mathrm{M}^{+}\right.$; found: 747.3713 $[\mathrm{M}+\mathrm{H}]^{+}$.

$N^{6}$-Benzoyl-8-( $N$-acetyl)-4-biphenyl-3', 5'-O-bis(tert-butyldimethylsilyl)-2'-deoxyadenosine (14d): GP-III was conducted with $13 \mathrm{~d}$ $(1.63 \mathrm{~g}, 1.91 \mathrm{mmol})$, which afforded the desired product as a yellow foam $(1.22 \mathrm{~g}, 1.53 \mathrm{mmol}, 80 \%)$. M.p. $65^{\circ} \mathrm{C} ;[\alpha]_{589 \mathrm{~nm}}^{25}=164.4$ $\left(c=0.5, \mathrm{CHCl}_{3}\right) ;{ }^{\prime} \mathrm{H} \mathrm{NMR}\left(400 \mathrm{MHz}_{1} \mathrm{CDCl}_{3}\right): \delta=8.66(\mathrm{~s}, 1 \mathrm{H}), 7.71(\mathrm{~d}$, $\left.J_{\mathrm{H}, \mathrm{H}}=6.6 \mathrm{~Hz}, 1 \mathrm{H}\right), 7.66\left(\mathrm{~d}, J_{\mathrm{H}, \mathrm{H}}=7.3 \mathrm{~Hz}, 2 \mathrm{H}\right), 7.61\left(\mathrm{~d}, J_{\mathrm{H}, \mathrm{H}}=7.3 \mathrm{~Hz}\right.$, $2 \mathrm{H}), 7.49-7.42(\mathrm{~m}, 3 \mathrm{H}), 7.40-7.34(\mathrm{~m}, 5 \mathrm{H}), 6.27\left(\mathrm{t}, J_{\mathrm{H}, \mathrm{H}}=7.0 \mathrm{~Hz}, 1 \mathrm{H}\right)$, 4.78-4.67 (m, 1 H), 4.21-3.92 (m, 2H), 3.78-3.69 (m, $1 \mathrm{H}), 3.43-3.29$ $(\mathrm{m}, 1 \mathrm{H}), 2.53(\mathrm{~s}, 3 \mathrm{H}), 1.96-1.88(\mathrm{~m}, 1 \mathrm{H}), 0.85(\mathrm{~s}, 9 \mathrm{H}), 0.84(\mathrm{~s}, 9 \mathrm{H})$, $0.09(\mathrm{~s}, 3 \mathrm{H}), 0.07(\mathrm{~s}, 3 \mathrm{H}), 0.03(\mathrm{~s}, 3 \mathrm{H}), 0.02 \mathrm{ppm}(\mathrm{s}, 3 \mathrm{H}) ;{ }^{13} \mathrm{C}$ NMR $\left(101 \mathrm{MHz} \mathrm{CDCl}_{3}\right): \delta=172.2,168.6,151.6,149.4,149.1,138.9,138.6$, $131.7,131.5,131.4,128.8,128.3,128.2,127.6,127.4,126.5,126.4$, $119.0,118.7,88.3,84.9,70.8,61.8,39.0,26.1,25.9,24.1,17.8,17.7$, $-4.6,-4.8 \mathrm{ppm}$; IR (ATR): $\tilde{\nu}=3033,2952,2928,2884,2856,1687$, $1612,1583,1520,1486,1462,1450,1434,1408,1356,1317,1277$, 1175, 1109, 1067, 1027, 1006, 949, 833, 776, 762, 710, 695, 666, 555, $505 \mathrm{~cm}^{-1}$; HRMS (FAB): $\mathrm{m} / \mathrm{z}$ calcd: $792.3851[\mathrm{M}]^{+}$; found: $793.3921[\mathrm{M}+\mathrm{H}]^{+}$.

General procedure IV for the desilylation of the $N^{6}-(B z)-8-(N-a c)-$ arylamine- $2^{\prime}-d A$ adducts to afford compounds $15 \mathrm{a}-\mathrm{d}$ : The appropriate compound 14 was dissolved in THF $(20 \mathrm{~mL})$, and TBAF ( 3 equiv, in THF) and $\mathrm{AcOH}$ ( 6 equiv) were then added simultaneously. The reaction mixture was stirred until the reaction was complete $(48 \mathrm{~h})$. The solvent was removed in vacuo. Purification of the residue by flash chromatography on silica gel, with elution with methanol in dichloromethane $(0 \rightarrow 5 \%)$, gave the desired product.

$N^{6}$-Benzoyl-8-( $N$-acetyl)-phenyl-2'-deoxyadenosine (15a): GP-IV was conducted with $14 \mathrm{a}(0.47 \mathrm{~g}, 0.67 \mathrm{mmol})$, which afforded the desired product as a yellow foam $(0.27 \mathrm{~g}, 0.55 \mathrm{mmol}, 83 \%)$. M.p. $143^{\circ} \mathrm{C} ;[\alpha]_{589 \mathrm{~nm}}^{25}=23.6\left(c=0.5, \mathrm{CHCl}_{3} / \mathrm{CH}_{3} \mathrm{OH} 1: 1, v / v\right) ;{ }^{1} \mathrm{H} N M R$ $\left(400 \mathrm{MHz},\left[\mathrm{D}_{6}\right] \mathrm{DMSO}, 323 \mathrm{~K}\right): \delta=10.51(\mathrm{~s}, 1 \mathrm{H}), 8.63(\mathrm{~s}, 1 \mathrm{H}), 7.56$ (d, $\left.J_{H, H}=7.5 \mathrm{~Hz}, 2 \mathrm{H}\right), 7.48-7.44(\mathrm{~m}, 1 \mathrm{H}), 7.40\left(\mathrm{t}, J_{\mathrm{H}, \mathrm{H}}=7.8 \mathrm{~Hz}, 2 \mathrm{H}\right), 7.38-$ $7.34(\mathrm{~m}, 2 \mathrm{H}), 7.33-7.27(\mathrm{~m}, 3 \mathrm{H}), 6.31\left(\mathrm{t}, J_{\mathrm{H}, \mathrm{H}}=7.0 \mathrm{~Hz}, 1 \mathrm{H}\right), 5.18(\mathrm{~d}$, $\left.J_{\mathrm{H}, \mathrm{H}}=3.7 \mathrm{~Hz}, 1 \mathrm{H}\right), 4.94-4.85(\mathrm{~m}, 1 \mathrm{H}), 4.52-4.45(\mathrm{~m}, 1 \mathrm{H}), 3.91(\mathrm{dd}$, $\left.J_{\mathrm{H}, \mathrm{H}}=7.8,4.9 \mathrm{~Hz}, 1 \mathrm{H}\right), 3.71$ (ddd, $\left.J_{\mathrm{H}, \mathrm{H}}=11.6,6.1,4.7 \mathrm{~Hz}, 1 \mathrm{H}\right), 3.56$ (ddd, $\left.J_{H, H}=12.0,6.1,5.8 \mathrm{~Hz}, 1 \mathrm{H}\right), 3.05-2.90(\mathrm{~m}, 1 \mathrm{H}), 2.20(\mathrm{~s}, 3 \mathrm{H})$, 2.00-1.86 ppm (m, 1 H); ${ }^{13} \mathrm{C}$ NMR (101 MHz, [D $]$ DMSO): $\delta=168.7$, $167.3,151.3,150.8,150.6,139.5,135.4,131.9,129.5,128.6,128.4$, $127.4,126.7,126.4,125.7,119.0,118.7,88.4,84.9,70.9,61.9,38.9$, 24.3 ppm; IR (ATR): $\tilde{\nu}=3247,2919,1674,1609,1583,1526,1493$, $1456,1352,1274,1176,1096,1053,1028,986,943,907,880,855$, $782,753,728,693,677,647,616,597,569,548,504,462,416$, $390 \mathrm{~cm}^{-1}$; UV $\left(\mathrm{CHCl}_{3} / \mathrm{CH}_{3} \mathrm{OH} 1: 1, v / v\right): \lambda_{\max }=240.4806,286.5065 \mathrm{~nm}$; HRMS $\left(\mathrm{ESI}^{+}\right)$: $\mathrm{m} / \mathrm{z}$ calcd: $488.1808[\mathrm{M}]^{+}$; found: $489.1877[\mathrm{M}+\mathrm{H}]^{+}$.

$N^{6}$-Benzoyl-8-( $N$-acetyl)-3,5-dimethylphenyl-2'-deoxyadenosine (15 b): GP-IV was conducted with $14 \mathrm{~b}(0.69 \mathrm{~g}, 0.93 \mathrm{mmol})$, which afforded the desired product as a yellow foam $(0.37 \mathrm{~g}, 0.71 \mathrm{mmol}$, $76 \%)$. M.p. $144.4^{\circ} \mathrm{C} ;[\alpha]_{589 \mathrm{~nm}}^{20}=220.6\left(c=0.5, \mathrm{CHCl}_{3} / \mathrm{CH}_{3} \mathrm{OH} 1: 1, v / v\right)$; 'H NMR (400 MHz, [D $]$ DMSO, $323 \mathrm{~K}): \delta=10.48(\mathrm{~s}, 1 \mathrm{H}), 8.63(\mathrm{~s}, 1 \mathrm{H})$, 
$7.56\left(\mathrm{~d}, J_{\mathrm{H}, \mathrm{H}}=7.6 \mathrm{~Hz}, 2 \mathrm{H}\right), 7.45\left(\mathrm{t}, J_{\mathrm{H}, \mathrm{H}}=7.4 \mathrm{~Hz}, 1 \mathrm{H}\right), 7.36\left(\mathrm{t}, J_{\mathrm{H}, \mathrm{H}}=\right.$ $7.7 \mathrm{~Hz}, 2 \mathrm{H}), 6.94(\mathrm{~s}, 1 \mathrm{H}), 6.91(\mathrm{~s}, 2 \mathrm{H}), 6.29\left(\mathrm{t}, J_{\mathrm{H}, \mathrm{H}}=7.0 \mathrm{~Hz}, 1 \mathrm{H}\right), 5.18$ $\left(\mathrm{d}, J_{\mathrm{H}, \mathrm{H}}=4.4 \mathrm{~Hz}, 1 \mathrm{H}\right), 4.99-4.89(\mathrm{~m}, 1 \mathrm{H}), 4.53-4.44(\mathrm{~m}, 1 \mathrm{H}), 3.92(\mathrm{dd}$, $\left.J_{\mathrm{H}, \mathrm{H}}=7.8,4.8 \mathrm{~Hz}, 1 \mathrm{H}\right), 3.72$ (ddd, $J_{\mathrm{H}, \mathrm{H}}=11.7,4.7,4.7 \mathrm{~Hz}, 1 \mathrm{H}$ ), 3.57 (ddd, $\left.J_{\mathrm{H}, \mathrm{H}}=11.9,7.0,5.1 \mathrm{~Hz}, 1 \mathrm{H}\right), 3.04-2.94(\mathrm{~m}, 1 \mathrm{H}), 2.21(\mathrm{~s}, 6 \mathrm{H})$, 2.20), $1.99-1.84 \mathrm{ppm}(\mathrm{m}, 1 \mathrm{H}) ;{ }^{13} \mathrm{C}$ NMR $\left(101 \mathrm{MHz},\left[\mathrm{D}_{6}\right] \mathrm{DMSO}\right): \delta=$ 172.2 , 168.7, 150.8, 150.1, 149.4, 140.3, 138.7, 131.6, 131.5, 128.9, $128.5,128.4,128.2,127.7,119.0,118.7,88.4,84.9,70.9,61.9,38.9$, $24.3,20.6 \mathrm{ppm}$; IR (ATR): $\tilde{\nu}=3302,3248,3101,2919,2864,2363$, $2339,1681,1609,1583,1526,1498,1463,1447,1350,1302,1283$, $1263,1178,1099,1082,1058,1037,986,961,936,904,852,825$, 797, 777, 739, 705, 684, 651, 631, 612, 575, 537, 515, 491, 479, 467, $450,432,415,404,390 \mathrm{~cm}^{-1}$; UV $\left(\mathrm{CHCl}_{3} / \mathrm{CH}_{3} \mathrm{OH} 1: 1, v / v\right): \lambda_{\max }=$ 229.9445, $284.0429 \mathrm{~nm}$; HRMS $\left(\mathrm{ESI}^{+}\right): \mathrm{m} / \mathrm{z}$ calcd: $516.2121 \mathrm{[M}^{+}$; found: $517.2193[\mathrm{M}+\mathrm{H}]^{+}$.

\section{$N^{6}$-Benzoyl-8-( $N$-acetyl)-4-methoxyphenyl-2'-deoxyadenosine} (15 c): GP-IV was conducted with $14 \mathrm{c}(1.02 \mathrm{~g}, 1.37 \mathrm{mmol})$, which afforded the desired product as a yellow foam $(0.55 \mathrm{~g}, 1.06 \mathrm{mmol}$, $78 \%$ ). M.p. $151^{\circ} \mathrm{C} ;[\alpha]_{589 \mathrm{~nm}}^{20}=227.2\left(c=0.5, \mathrm{CHCl}_{3} / \mathrm{CH}_{3} \mathrm{OH} 1: 1, v / v\right)$; 'H NMR (400 MHz, [D $\mathrm{D}_{6}$ DMSO, $\left.323 \mathrm{~K}\right): \delta=10.49(\mathrm{~s}, 1 \mathrm{H}), 8.63(\mathrm{~s}, 1 \mathrm{H})$, $7.54\left(\mathrm{~d}, J_{\mathrm{H}, \mathrm{H}}=6.7 \mathrm{~Hz}, 2 \mathrm{H}\right), 7.45\left(\mathrm{t}, J_{\mathrm{H}, \mathrm{H}}=7.4 \mathrm{~Hz}\right), 7.36\left(\mathrm{t}, J_{\mathrm{H}, \mathrm{H}}=7.6 \mathrm{~Hz}\right.$, $2 \mathrm{H}), 7.25\left(\mathrm{~d}, J_{\mathrm{H}, \mathrm{H}}=8.8 \mathrm{~Hz}, 2 \mathrm{H}\right), 6.94\left(\mathrm{~d}, J_{\mathrm{H}, \mathrm{H}}=8.4 \mathrm{~Hz}, 2 \mathrm{H}\right), 6.33(\mathrm{dd}$ $\left.J_{H, H}=7.0,6.9 \mathrm{~Hz}, 1 \mathrm{H}\right), 5.20\left(\mathrm{~d}, J_{\mathrm{H}, \mathrm{H}}=4.4 \mathrm{~Hz}, 1 \mathrm{H}\right), 4.95-4.89(\mathrm{~m}, 1 \mathrm{H})$, $4.55-4.46(\mathrm{~m}, 1 \mathrm{H}), 3.92\left(\mathrm{dd}, J_{\mathrm{H}, \mathrm{H}}=7.7,4.7 \mathrm{~Hz}, 1 \mathrm{H}\right), 3.73(\mathrm{~s}, 3 \mathrm{H})$ $3.74-3.69(\mathrm{~m}, 1 \mathrm{H}), 3.57\left(\mathrm{ddd}, J_{\mathrm{H}, \mathrm{H}}=11.7,5.9,4.8 \mathrm{~Hz}, 1 \mathrm{H}\right), 3.06-2.93$ $(\mathrm{m}, 1 \mathrm{H}), 2.20(\mathrm{~s}, 3 \mathrm{H}), 2.02-1.91 \mathrm{ppm}(\mathrm{m}, 1 \mathrm{H}) ;{ }^{13} \mathrm{C}$ NMR $(101 \mathrm{MHz}$, [D $\mathrm{D}_{6}$ ]DMSO): $\delta=172.1,168.6,151.4,150.7,149.3,147.5,139.4,134.5$, $133.8,133.5,133.0,131.3,128 ., 128.1,127.8,121.7,114.6,88.3,84.8$, $70.8,61.8,55.2,37.1,24.1 \mathrm{ppm}$; IR (ATR): $\tilde{\nu}=3247,2931,2837$, $1670,1607,1584,1530,1507,1462,1441,1355,1283,1243,1172$, $1136,1096,1053,1027,987,943,908,879,863,831,797,775,719$, $661,608,581,548,527,491,455,432,417,390,381 \mathrm{~cm}^{-1}$; UV $\left(\mathrm{CHCl}_{3} / \mathrm{CH}_{3} \mathrm{OH} 1: 1, v / v\right): \lambda_{\max }=248.7985,307.5786 \mathrm{~nm}$; HRMS $\left(\mathrm{ESI}{ }^{+}\right):$ $\mathrm{m} / \mathrm{z}$ calcd: $518.1914[\mathrm{M}]^{+}$; found: $519.1981[\mathrm{M}+\mathrm{H}]^{+}$.

$N^{6}$-Benzoyl-8-( $N$-acetyl)-4-biphenyl-2'-deoxyadenosine (15 d): GPIV was conducted with $14 \mathrm{~d}(1.20 \mathrm{~g}, 1.51 \mathrm{mmol})$, which afforded the desired product as a yellow foam $(0.78 \mathrm{~g}, 1.38 \mathrm{mmol}, 91 \%)$. M.p. $147^{\circ} \mathrm{C} ;[\alpha]_{589 \mathrm{~nm}}^{25}=183.8\left(\mathrm{c}=0.5, \mathrm{CHCl}_{3} / \mathrm{CH}_{3} \mathrm{OH} 1: 1, v / v\right) ;{ }^{1} \mathrm{H}$ NMR ( $400 \mathrm{MHz},\left[\mathrm{D}_{6}\right.$ ]DMSO, $\left.323 \mathrm{~K}\right): \delta=10.54(\mathrm{~s}, 1 \mathrm{H}), 8.64(\mathrm{~s}, 1 \mathrm{H}), 7.71(\mathrm{~d}$, $\left.J_{\mathrm{H}, \mathrm{H}}=6.6 \mathrm{~Hz}, 1 \mathrm{H}\right), 7.66\left(\mathrm{~d}, J_{\mathrm{H}, \mathrm{H}}=7.3 \mathrm{~Hz}, 2 \mathrm{H}\right), 7.61\left(\mathrm{~d}, J_{\mathrm{H}, \mathrm{H}}=7.3 \mathrm{~Hz}\right.$, $2 \mathrm{H}), 7.49-7.42(\mathrm{~m}, 3 \mathrm{H}), 7.40-7.34(\mathrm{~m}, 5 \mathrm{H}), 6.34\left(\mathrm{dd}, J_{\mathrm{H}, \mathrm{H}}=7.0\right.$, $6.9 \mathrm{~Hz}, 1 \mathrm{H}), 5.20(\mathrm{brs}, 1 \mathrm{H}), 4.90(\mathrm{brs}, 1 \mathrm{H}), 4.51-4.47(\mathrm{~m}, 1 \mathrm{H}), 3.92$ (dd, $\left.J_{\mathrm{H}, \mathrm{H}}=7.9,4.9 \mathrm{~Hz}, 1 \mathrm{H}\right), 3.72\left(\mathrm{dd}, J_{\mathrm{H}, \mathrm{H}}=11.7,4.4 \mathrm{~Hz}, 1 \mathrm{H}\right), 3.59-$ $3.54(\mathrm{~m}, 1 \mathrm{H}), 3.05-2.96(\mathrm{~m}, 1 \mathrm{H}), 2.20(\mathrm{~s}, 3 \mathrm{H}), 2.01-1.90 \mathrm{ppm}(\mathrm{m}$, $1 \mathrm{H}) ;{ }^{13} \mathrm{C}$ NMR $\left(101 \mathrm{MHz},\left[\mathrm{D}_{6}\right] \mathrm{DMSO}\right): \delta=172.2,168.6,151.6,149.4$, $149.1,138.9,138.6,131.7,131.5,131.4,128.8,128.3,128.2,127.6$, $127.4,126.5,126.4,119.0,118.7,88.3,84.9,70.8,61.8,39.0$, $24.1 \mathrm{ppm}$; IR (ATR): $\ddot{\nu}=3270,3063,3031,2933,2861,1678,1607$ $1583,1518,1485,1460,1448,1402,1348,1319,1276,1176,1098$, $1055,1025,1007,988,944,839,788,763,719,694,665,640,596$, $555,503,466,398 \mathrm{~cm}^{-1} ; \mathrm{UV}\left(\mathrm{CHCl}_{3} / \mathrm{CH}_{3}=\mathrm{H} 1: 1, \mathrm{v} / \mathrm{v}\right): \lambda_{\max }=249.9076$, $302.0333 \mathrm{~nm}$; HRMS (FAB): $\mathrm{m} / \mathrm{z}$ calcd: $564.2121 \mathrm{[M]}^{+}$; found: $565.2196[\mathrm{M}+\mathrm{H}]$

General Procedure $V$ for the $5^{\prime}$-O-dimethoxytritylation of the $N^{6}$ (Bz)-8-(N-ac)-arylamine-2'-dA adducts to afford compounds $16 \mathrm{a}-$ d: The appropriate compound $\mathbf{1 5}$ was dissolved in anhydrous pyridine $(20 \mathrm{~mL})$ under nitrogen and 4,4'-dimethoxytrityl chloride ( 1 equiv) and silver nitrate ( 2 equiv) were added. The mixture was stirred at room temperature until the reaction was complete $(\approx 3 \mathrm{~h})$. It was then diluted with dichloromethane and washed with brine, and the aqueous layer was extracted three times with dichloromethane. The combined organic layers were dried over sodium sulfate and filtered, and the solvent was removed in vacuo. The residue was purified by flash chromatography on ALOX (act. III) with methanol in dichloromethane $(0 \rightarrow 2 \%)$ to afford the desired product.

$N^{6}$-Benzoyl-8-( $N$-acetyl)-phenyl-5'-O-dimethoxytrityl-2'-deoxyadenosine (16a): GP-V was conducted with $15 \mathrm{a}(0.28 \mathrm{~g}$, $0.58 \mathrm{mmol}$ ), which afforded the desired product as a yellow foam $(0.32 \mathrm{~g}, 0.41 \mathrm{mmol}, 71 \%)$. M.p. $128^{\circ} \mathrm{C} ;[\alpha]_{589 \mathrm{~nm}}^{25}=104.4 \quad(c=0.5$,

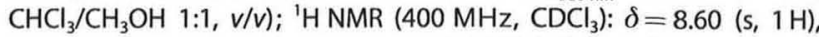
7.56-7.51 (m, 2H), 7.31-7.25 (m, 8H), 7.22-7.18 (m, $3 \mathrm{H}), 7.18-7.11$ $(\mathrm{m}, 5 \mathrm{H}), 7.84-7.78(\mathrm{~m}, 5 \mathrm{H}), 6.38\left(\mathrm{dd}, J_{\mathrm{H}, \mathrm{H}}=7.0,5.8 \mathrm{~Hz}, 1 \mathrm{H}\right), 4.71(\mathrm{~d}$, $\left.J_{\mathrm{H}, \mathrm{H}}=3.7 \mathrm{~Hz}, 1 \mathrm{H}\right), 4.22-4.15(\mathrm{~m}, 1 \mathrm{H}), 3.78(\mathrm{~s}, 6 \mathrm{H}), 3.57\left(\mathrm{dd}, J_{\mathrm{H}, \mathrm{H}}=7.8\right.$, $4.9 \mathrm{~Hz}, 1 \mathrm{H}), 3.12-3.04(\mathrm{~m}, 3 \mathrm{H}), 2.57(\mathrm{~s}, 3 \mathrm{H}), 1.46-1.41 \mathrm{ppm}(\mathrm{m}, 1 \mathrm{H})$; ${ }^{13} \mathrm{C}$ NMR: $\left(100 \mathrm{MHz}, \mathrm{CDCl}_{3}\right): \delta=159.2,159.1,145.9,151.6,136.6$, $131.6,131.4,130.8,130.6,130.6,130.5,129.8,129.6,129.5,128.8$, $128.7,128.6,128.3,113.6,113.5,86.8,85.6,75.1,54.8,43.5,36.1$, $24.7 \mathrm{ppm}$; IR (ATR): $\tilde{v}=3277,2933,2836,1682,1608,1582,1508$, $1459,1400,1352,1281,1247,1175,1063,1030,951,828,790,755$, 726, 696, 644, 581, 549, $504 \mathrm{~cm}^{-1}$; HRMS $\left(\mathrm{ESI}^{+}\right): \mathrm{m} / \mathrm{z}$ calcd: $790.3115\left[\mathrm{M}^{+}\right.$; found: $791.3154[\mathrm{M}+\mathrm{H}]^{+}$.

$N^{6}$-Benzoyl-8-( $N$-acetyl)-3,5-dimethylphenyl-5'-O-dimethoxytrityl2'-deoxyadenosine (16 b): GP-V was conducted with $15 \mathrm{~b}(0.66 \mathrm{~g}$, $1.29 \mathrm{mmol}$ ), which afforded the desired product as a yellow foam $(0.67 \mathrm{~g}, 0.83 \mathrm{mmol}, 64 \%)$. M.p. $137^{\circ} \mathrm{C} ;[\alpha]_{589 \mathrm{~nm}}^{25}=144.6(c=0.5$, $\left.\mathrm{CHCl}_{3} / \mathrm{CH}_{3} \mathrm{OH} 1: 1, v / v\right)$; ${ }^{1} \mathrm{H}$ NMR: $\left(400 \mathrm{MHz}, \mathrm{CDCl}_{3}\right): \delta=8.60(\mathrm{~s}, 1 \mathrm{H})$, 7.29-7.27 (m, 4H), 7.18-7.15 (m, 7H), $7.03(\mathrm{~s}, 1 \mathrm{H}), 6.95(\mathrm{~s}, 2 \mathrm{H})$, 6.85-6.81 (m, 7H), $6.30\left(\mathrm{dd}, J_{\mathrm{H}, \mathrm{H}}=9.8,5.3 \mathrm{~Hz}, 1 \mathrm{H}\right), 4.83-4.76(\mathrm{~m}$, $1 \mathrm{H}), 4.27-4.23(\mathrm{~m}, 1 \mathrm{H}), 4.02-3.94(\mathrm{~m}, 2 \mathrm{H}), 3.77(\mathrm{~s}, 6 \mathrm{H}), 3.57-3.50$ $(\mathrm{m}, 1 \mathrm{H}), 2.29-2.23(\mathrm{~m}, 1 \mathrm{H}), 2.18(\mathrm{~s}, 6 \mathrm{H}), 2.01 \mathrm{ppm}(\mathrm{s}, 3 \mathrm{H}) ;{ }^{13} \mathrm{C}$ NMR $\left(100 \mathrm{MHz}_{1} \mathrm{CDCl}_{3}\right): \delta=160.4,159.9,159.8,152.3,151.2,150.1,146.7$, $141.0,140.9,137.1,133.0,132.7,131.4,131.4,131.1,131.0,130.6$, $130.3,130.1,129.9,129.5,129.3,128.5,127.8,113.9,113.8,113.8$, 113.7, 88.8, 86.6, 73.4, 55.7, 55.6, 47.1, 38.0, 24.7, 21.2, 21.2 ppm; IR (ATR): $\tilde{\nu}=2930,2835,1693,1608,1582,1507,1461,1368,1349$, $1281,1245,1174,1109,1073,1051,1029,961,916,827,800,790$, $754,726,697,642,581,542,488,466,389 \mathrm{~cm}^{-1}$; HRMS (FAB): $\mathrm{m} / \mathrm{z}$ calcd: $818.3428\left[\mathrm{M}^{+}\right.$; found: $819.3479[\mathrm{M}+\mathrm{H}]^{+}$.

$N^{6}$-Benzoyl-8-( $\mathrm{N}$-acetyl)-4-methoxyphenyl-5'-0-dimethoxytrityl2'-deoxyadenosine (16 c): GP-V was conducted with $15 \mathrm{c}(0.54 \mathrm{~g}$, $1.03 \mathrm{mmol})$, which afforded the desired product as a yellow foam $(0.37 \mathrm{~g}, 0.45 \mathrm{mmol}, 43 \%)$. M.p. $139^{\circ} \mathrm{C} ;[\alpha]_{589 \mathrm{~nm}}^{25}=139.4 \quad(c=0.5$, $\left.\mathrm{CHCl}_{3} / \mathrm{CH}_{3} \mathrm{OH} 1: 1, v / v\right)$; 'H NMR $\left(400 \mathrm{MHz}, \mathrm{CDCl}_{3}\right): \delta=8.61(\mathrm{~s}, 1 \mathrm{H})$, 7.57-7.53 $(\mathrm{m}, 2 \mathrm{H}), 7.44-7.38(\mathrm{~m}, 1 \mathrm{H}), 7.32-7.27(\mathrm{~m}, 7 \mathrm{H}), 7.19-7.13$ $(\mathrm{m}, 6 \mathrm{H}), 6.85-6.81(\mathrm{~m}, 6 \mathrm{H}), 6.40\left(\mathrm{dd}, J_{\mathrm{H}, \mathrm{H}}=9.7,5.3 \mathrm{~Hz}, 1 \mathrm{H}\right), 4.76-$ $4.71(\mathrm{~m}, 1 \mathrm{H}), 4.23-4.20(\mathrm{~m}, 1 \mathrm{H}), 4.01-3.95(\mathrm{~m}, 2 \mathrm{H}), 3.80(\mathrm{~s}, 6 \mathrm{H})$, $3.78(\mathrm{~s}, 3 \mathrm{H}), 2.58 \mathrm{ppm}(\mathrm{s}, 3 \mathrm{H}) ;{ }^{13} \mathrm{C}$ NMR $\left(100 \mathrm{MHz}, \mathrm{CDCl}_{3}\right): \delta=$ $165.3,158.0,154.7,152.8,150.4,147.9,145.0,144.6,135.8,135.6$, $134.0,132.8,129.7,129.6,128.4,128.3,127.6,126.5,126.2,120.8$, $113.8,113.0,86.6,84.7,74.7,64.1,55.2,55.1,35.1,24.7 \mathrm{ppm}$; IR (ATR): $\tilde{v}=3356,3057,2999,2932,2835,2361,1735,1670,1609$, $1563,1462,1444,1372,1301,1177,1034,910,828,791,754,726$, 617, $584 \mathrm{~cm}^{-1}$; MS (FAB): $\mathrm{m} / \mathrm{z}$ calcd: $820.3221\left[\mathrm{M}^{+}\right.$; found: $821.3263[\mathrm{M}+\mathrm{H}]^{+}$.

$\mathrm{N}^{6}$-Benzoyl-8-( $\mathrm{N}$-acetyl)-4-biphenyl-5'-O-dimethoxytrityl-2'-deoxyadenosine (16d): GP-V was conducted with $15 \mathrm{~d}(0.77 \mathrm{~g}$, $1.36 \mathrm{mmol})$, which afforded the desired product as a yellow foam $(0.74 \mathrm{~g}, 0.85 \mathrm{mmol}, 63 \%)$. M.p. $160^{\circ} \mathrm{C} ;[\alpha]_{589 \mathrm{~nm}}^{25}=145.8 \quad(c=0.5$, $\left.\mathrm{CHCl}_{3} / \mathrm{CH}_{3} \mathrm{OH} 1: 1, v / v\right)$; 'H NMR $\left(400 \mathrm{MHz}, \mathrm{CDCl}_{3}\right): \delta=8.52(\mathrm{~s}, 1 \mathrm{H})$, 7.52-7.43 $(\mathrm{m}, 8 \mathrm{H}), 7.35-7.30(\mathrm{~m}, 4 \mathrm{H}), 7.28-7.23(\mathrm{~m}, 4 \mathrm{H}), 7.19-7.17$ $(\mathrm{m}, 3 \mathrm{H}), 7.09-7.05(\mathrm{~m}, 4 \mathrm{H}), 6.75-6.72(\mathrm{~m}, 4 \mathrm{H}), 6.32\left(\mathrm{dd}, J_{\mathrm{H}, \mathrm{H}}=9.7\right.$, $5.3 \mathrm{~Hz}, 1 \mathrm{H}), 4.66-4.61(\mathrm{~m}, 1 \mathrm{H}), 4.13-4.10(\mathrm{~m}, 1 \mathrm{H}), 3.92-3.83(\mathrm{~m}$, 
$2 \mathrm{H}), 3.70(\mathrm{~s}, 6 \mathrm{H}), 2.49 \mathrm{ppm}(\mathrm{s}, 3 \mathrm{H}) ;{ }^{13} \mathrm{C}$ NMR $\left(101 \mathrm{MHz}, \mathrm{CDCl}_{3}\right): \delta=$ $163.1,152.4,147.1,142.1,140.9,139.8,139.6,133.9,131.5,129.9$, $129.3,129.2,129.0,128.2,128.1,128.0,128.0,127.3,127.2,113.3$, 87.5, 82.8, 67.1, 61.1, 55.4, 31.1 ppm; IR (ATR): $\tilde{v}=3033,2966,2932$, $2837,2251,1682,1608,1583,1508,1487,1461,1447,1409,1353$, $1319,1281,1247,1176,1157,1127,1065,1029,1008,976,901,828$, 790, 764, 724, 698, 666, 640, 581, 562, $523 \mathrm{~cm}^{-1}$; HRMS (FAB): $\mathrm{m} / \mathrm{z}$ calcd: $866.3428[M]^{+}$; found: $867.3457[\mathrm{M}+\mathrm{H}]^{+}$.

General Procedure $\mathrm{VI}$ for the $3^{\prime}-\mathrm{O}$-phosphitylation of the $\mathrm{N}^{6}$ (benzoyl)-8-( $N$-acetyl)-arylamine-5'-O-DMTr-2'-dA adducts to afford compounds $17 \mathrm{a}-\mathrm{d}$ : The appropriate compound 16 was dissolved in anhydrous $\mathrm{CH}_{2} \mathrm{Cl}_{2}(5 \mathrm{~mL})$ and acetonitrile $(5 \mathrm{~mL})$ under nitrogen, and $\mathrm{DCl}$ (1.0 equiv) was added. The reaction mixture was treated with bis- $N, N^{\prime}$-diisopropylamino-(2-O-cyanoethyl)phosphate (1.5 equiv). The mixture was stirred at room temperature until the reaction was complete $(\approx 2 \mathrm{~h}$ ). It was then diluted with dichloromethane and washed with water. The aqueous layer was extracted three times with $\mathrm{CH}_{2} \mathrm{Cl}_{2}$. The combined organic layers were dried over sodium sulfate and filtered, and the solvent was removed in vacuo. The residue was purified by flash chromatography on ALOX (act. III) with methanol in $\mathrm{CH}_{2} \mathrm{Cl}_{2}(0 \rightarrow 1 \%)$. The product was redissolved in benzene and gave the desired product as a colourless solid after freeze-drying.

$N^{6}$-Benzoyl-[8-( $N$-acetyl)-phenylamino]-5'-O-dimethoxytrityl-2'deoxyadenosine-3'-O-( $\beta$-cyanoethyl- $N, N^{\prime}$-diisopropylphosphoramidite (17 a): GP-VI was conducted with 16 a $(0.31 \mathrm{~g}, 0.40 \mathrm{mmol})$, which afforded the desired product as a colourless solid $(0.30 \mathrm{~g}$, $0.30 \mathrm{mmol}, 76 \%$ ). M.p. $95^{\circ} \mathrm{C}$; ${ }^{1} \mathrm{H}$ NMR $\left(400 \mathrm{MHz}, \mathrm{C}_{6} \mathrm{D}_{6}\right): \delta=8.33$ (s, $1 \mathrm{H}), 7.72-7.65(\mathrm{~m}, 5 \mathrm{H}), 7.55-7.47(\mathrm{~m}, 5 \mathrm{H}), 7.15-7.10(\mathrm{~m}, 4 \mathrm{H}), 6.77-$ $6.62(\mathrm{~m}, 9 \mathrm{H}), 6.63-6.55(\mathrm{~m}, 1 \mathrm{H}), 5.18-5.00(\mathrm{~m}, 1 \mathrm{H}), 4.75-4.62(\mathrm{~m}$, $1 \mathrm{H}), 3.88-3.76(\mathrm{~m}, 2 \mathrm{H}), 3.56-3.42(\mathrm{~m}, 2 \mathrm{H}), 3.33(\mathrm{~s}, 6 \mathrm{H}), 3.27-3.17$ $(\mathrm{m}, 2 \mathrm{H}), 2.39(\mathrm{~s}, 3 \mathrm{H}), 1.82-1.67(\mathrm{~m}, 2 \mathrm{H}), 1.09-0.98 \mathrm{ppm}(\mathrm{m}, 12 \mathrm{H})$; ${ }^{13} \mathrm{C}$ NMR $\left(101 \mathrm{MHz}, \mathrm{C}_{6} \mathrm{D}_{6}\right): \delta=163.8,159.2,151.7,151.6,149.9$, $146.7,145.8,136.5,136.4,134.5,133.9,131.9,131.6,131.5,130.7$, $130.5,129.7,129.5,128.6,128.5,127.4,127.1,122.6,113.3,86.9$, 85.6, 74.9, 64.8, 59.0, 54.8, 43.6, 36.1, 31.1, 24.7, 24.6, 20.0 ppm; ${ }^{31} \mathrm{P}$ NMR $\left(162 \mathrm{MHz}, \mathrm{C}_{6} \mathrm{D}_{6}\right): \delta=162.78,162.69,161.88,161.83 \mathrm{ppm}$; IR (ATR): $\ddot{\nu}=2965,2931,2836,1678,1635,1604,1578,1508,1460$, $1446,1410,1396,1366,1327,1293,1248,1200,1177,1155,1125$, $1057,1030,1002,977,900,879,828,791,754,725,697,643,582$, 551, $521 \mathrm{~cm}^{-1}$; MS $\left(E S I^{+}\right): \mathrm{m} / z$ calcd: $990.4\left[\mathrm{M}^{+}\right.$; found: 990.5 $[\mathrm{M}+\mathrm{H}]^{+}$.

$N^{6}$-Benzoyl-[8-( $N$-acetyl)-3,5-dimethylphenylamino]-5'-O-dimethoxytrityl-2'-deoxyadenosine-3'-O-( $\beta$-cyanoethyl- $N, N^{\prime}$-diisopropylphosphoramidite (17b): GP-VI was conducted with $16 \mathrm{~b}(0.66 \mathrm{~g}$, $0.81 \mathrm{mmol})$, which afforded the desired product as a colourless solid $(0.29 \mathrm{~g}, 0.29 \mathrm{mmol}, 36 \%)$. M.p. $103^{\circ} \mathrm{C} ;[\alpha]_{589 \mathrm{~nm}}^{20}=304.0(\mathrm{c}=0.5$, $\left.\mathrm{CHCl}_{3}\right)$; 'H NMR: $\left(400 \mathrm{MHz}, \mathrm{C}_{6} \mathrm{D}_{6}\right): \delta=8.26(\mathrm{~s}, 1 \mathrm{H}), 7.70-7.68(\mathrm{~m}$, $2 \mathrm{H}), 7.53-7.51(\mathrm{~m}, 4 \mathrm{H}), 7.13-7.09(\mathrm{~m}, 3 \mathrm{H}), 7.05-7.02(\mathrm{~m}, 2 \mathrm{H}), 6.94-$ $6.80(\mathrm{~m}, 3 \mathrm{H}), 6.72-6.62(\mathrm{~m}, 6 \mathrm{H}), 6.56-6.48(\mathrm{~m}, 1 \mathrm{H}), 5.20-4.91(\mathrm{~m}$, $3 \mathrm{H}), 4.69(\mathrm{~m}, 1 \mathrm{H}), 4.00-3.75(\mathrm{~m}, 2 \mathrm{H}), 3.50-3.40(\mathrm{~m}, 2 \mathrm{H}), 3.33(\mathrm{~s}$, $6 \mathrm{H}), 3.30-3.20(\mathrm{~m}, 2 \mathrm{H}), 1.90(\mathrm{~s}, 6 \mathrm{H}), 1.80-1.63(\mathrm{~m}, 2 \mathrm{H}), 1.19-1.15$ $(\mathrm{m}, 1 \mathrm{H}), 1.12(\mathrm{~s}, 3 \mathrm{H}), 1.10(\mathrm{~s}, 3 \mathrm{H}), 1.11(\mathrm{~s}, 3 \mathrm{H}), 0.99 \mathrm{ppm}(\mathrm{s}, 3 \mathrm{H})$; ${ }^{13} \mathrm{C}$ NMR: $\left(100 \mathrm{MHz}, \mathrm{C}_{6} \mathrm{D}_{6}\right): \delta=159.2,159.1,155.6,153.3,146.0$, $139.5,136.7,136.6,131.4,130.8,130.7,129.4,129.3,128.5,127.0$, $113.6,113.5,87.9,86.1,77.4,59.1,54.8,43.6,36.3,24.7,24.6,24.5$, 24.5, $21.1 \mathrm{ppm}$; ${ }^{31} \mathrm{P}$ NMR $\left(162 \mathrm{MHz}, \mathrm{C}_{6} \mathrm{D}_{6}\right): \delta=162.60,162.58$ ， $161.77,161.72 \mathrm{ppm}$; IR (ATR): $\tilde{\nu}=2965,2929,2872,2836,1697$, $1634,1607,1508,1462,1445,1396,1365,1327,1296,1248,1200$, $1177,1156,1116,1073,1031,976,899,879,828,800,770,754,725$, $703,681,641,583,521,463,393 \mathrm{~cm}^{-1}$; MS (FAB): $\mathrm{m} / \mathrm{z}$ calcd: 1018.4 $[M]^{+}$; found: $1019.3[M+H]^{+}$.
$N^{6}$-Benzoyl-[8-( $N$-acetyl)-4-methoxyphenylamino]-5'-O-dimethoxytrityl-2'-deoxyadenosine-3'-O-( $\beta$-cyanoethyl- $N, N^{\prime}$-diisopropylphosphoramidite (17c): GP-VI was conducted with $16 \mathrm{c}(0.35 \mathrm{~g}$, $0.43 \mathrm{mmol})$, which afforded the desired product as a colourless solid $(0.28 \mathrm{~g}, 0.28 \mathrm{mmol}, 63 \%)$. M.p. $96^{\circ} \mathrm{C} ;[\alpha]_{589 \mathrm{~nm}}^{20}=84.6(c=0.5$, $\left.\mathrm{CHCl}_{3}\right)$; ${ }^{1} \mathrm{H}$ NMR $\left(400 \mathrm{MHz}, \mathrm{C}_{6} \mathrm{D}_{6}\right): \delta=8.29(\mathrm{~s}, 1 \mathrm{H}), 7.91-7.89(\mathrm{~m}$, $2 \mathrm{H}), 7.67-7.51(\mathrm{~m}, 6 \mathrm{H}), 7.48-7.31(\mathrm{~m}, 10 \mathrm{H}), 7.13-6.91(\mathrm{~m}, 12 \mathrm{H})$, 6.78-6.75 (m, 12H), 6.56-6.48 (m, 1 H), 5.20-4.91 (m, $1 \mathrm{H}), 4.00-3.75$ $(\mathrm{m}, 2 \mathrm{H}), 3.50-3.40(\mathrm{~m}, 2 \mathrm{H}), 3.33(\mathrm{~s}, 6 \mathrm{H}), 3.30-3.20(\mathrm{~m}, 2 \mathrm{H}), 1.90(\mathrm{~s}$, $6 \mathrm{H}), 1.80-1.63(\mathrm{~m}, 2 \mathrm{H}), 1.19-1.15(\mathrm{~m}, 1 \mathrm{H}), 1.12(\mathrm{~s}, 3 \mathrm{H}), 1.10(\mathrm{~s}, 3 \mathrm{H})$, $1.11(\mathrm{~s}, 3 \mathrm{H}), 0.99 \mathrm{ppm}(\mathrm{s}, 3 \mathrm{H}) ;{ }^{13} \mathrm{C}$ NMR $\left(100 \mathrm{MHz}, \mathrm{C}_{6} \mathrm{D}_{6}\right): \delta=159.2$, $159.1,155.6,153.3,146.0,139.5,136.7,136.6,131.4,130.8,130.7$, $129.4,129.3,128.5,127.0,113.6,113.5,87.9,86.1,77.4$ 59.1, 54.8, 43.6, 36.3, 24.7, 24.6, 24.5, 24.5, $21.1 \mathrm{ppm}$; ${ }^{31} \mathrm{P}$ NMR (162 MHz, [D] ]benzene): $\delta=162.64,162.45,161.81,161.74 \mathrm{ppm}$; IR (ATR): $\ddot{\nu}=$ $3033,2964,2932,2836,2545,2389,2250,2220,2181,2163,2143$, $2111,2049,2008,1977,1894,1680,1607,1582,1508,1461,1446$, $1396,1364,1286,1246,1201,1176,1156,1126,1029,977,900,828$, $791,772,754,724,701,681,664,641,581,548,523,461,428,410$, $392 \mathrm{ppm}$; MS (FAB): $\mathrm{m} / \mathrm{z}$ calcd: $1020.4 \mathrm{CM}^{+}$; found: 1022.3 $[\mathrm{M}+2 \mathrm{H}]^{+}$.

$N^{6}$-Benzoyl-[8-( $N$-acetyl)-4-biphenylamino]-5'-O-dimethoxytrityl2'-deoxyadenosine-3'-O-( $\beta$-cyanoethyl- $N, N^{\prime}$-diisopropylphosphoramidite (17 d): GP-VI was conducted with $16 \mathrm{~d}(0.72 \mathrm{~g}, 0.83 \mathrm{mmol})$, which afforded the desired product as a colourless solid $(0.51 \mathrm{~g}$, $0.48 \mathrm{mmol}, 58 \%)$. M.p. $60.4^{\circ} \mathrm{C} ; \quad[\alpha]_{589 \mathrm{~nm}}^{20}=166 \quad\left(c=0.5, \quad \mathrm{CHCl}_{3}\right)$; 'H NMR $\left(400 \mathrm{MHz}, \mathrm{C}_{6} \mathrm{D}_{6}\right): \delta=8.05(\mathrm{~s}, 1 \mathrm{H}), 7.71-7.63(\mathrm{~m}, 2 \mathrm{H}), 7.54-$ $7.46(\mathrm{~m}, 4 \mathrm{H}), 7.33-7.20(\mathrm{~m}, 4 \mathrm{H}), 7.20-6.99(\mathrm{~m}, 12 \mathrm{H}), 6.95-6.88(\mathrm{~m}$, $3 \mathrm{H}), 6.72-6.60(\mathrm{~m}, 6 \mathrm{H}), 4.78-4.70(\mathrm{~m}, 1 \mathrm{H}), 3.86-3.75(\mathrm{~m}, 2 \mathrm{H}), 3.48-$ $3.39(\mathrm{~m}, 1 \mathrm{H}), 3.30(\mathrm{~s}, 3 \mathrm{H}), 3.28(\mathrm{~s}, 3 \mathrm{H}), 3.15-3.01(\mathrm{~m}, 2 \mathrm{H}), 2.96-2.88$ $(\mathrm{m}, 2 \mathrm{H}), 2.38(\mathrm{~s}, 3 \mathrm{H}), 1.53-1.46(\mathrm{~m}, 2 \mathrm{H}), 1.09-0.99 \mathrm{ppm}(\mathrm{m}, 12 \mathrm{H})$; ${ }^{13} \mathrm{C}$ NMR $\left(100 \mathrm{MHz}, \mathrm{C}_{6} \mathrm{D}_{6}\right): \delta=159.2,149.7,141.1,136.0,135.9$, $134.9,132.6,131.9,130.8,130.6,129.0,128.8,128.7,128.6,127.9$, $127.1,127.0,119.7,117.6,113.6,87.0,85.8,59.3,58.0,45.4$, $20.6 \mathrm{ppm} ;{ }^{31}$ P NMR $\left(162 \mathrm{MHz}, \mathrm{C}_{6} \mathrm{D}_{6}\right): \delta=162.71,162.67,161.91$, 161.84 ppm; IR (ATR): $\ddot{v}=3033,2966,2932,2837,2251,1682,1608$, $1583,1508,1487,1461,1447,1409,1353,1319,1281,1247,1176$, $1157,1127,1065,1029,1008,976,901,828,790,764,724,698$, $666,640,581,562,523 \mathrm{~cm}^{-1}$; MS (FAB): $\mathrm{m} / \mathrm{z}$ calcd: $1066.3\left[\mathrm{M}^{+}\right.$; found: $1068.2[\mathrm{M}+2 \mathrm{H}]^{+}$.

Oligonucleotide synthesis: Oligonucleotides were synthesised on a $1 \mu \mathrm{mol}$ scale with use of Pac-protected dA, iPrPac-protected dG, ac-protected dC and T phosphoramidites on a 394 DNA synthesiser (Applied Biosystems) and of phosphoramidites and solid supports purchased from ChemGenes. The manufacturer's standard synthesis protocol was used, except that on incorporation of the modified phosphoramidites the coupling was repeated three times, each for $500 \mathrm{~s}$. The oligonucleotides were purified by HPLC with triethylammonium acetate buffer $(\mathrm{pH} 6.9$, solvent 1$)$ and acetonitrile (solvent 2) on a C-18 reversed-phase column with UV detection. The solvent gradient was as follows: initially $99 \%$ solvent 1 , then a 50 min linear gradient to $23 \%$ solvent 2; $10 \mathrm{~min}$ with $100 \%$ solvent $2 ; 10 \mathrm{~min}$ with $100 \%$ solvent 1 .

HRMS data for the oligonucleotides are given in Table 5.

Thermal melting studies: Equal amounts of the two complementary strands $(2 \mathrm{nmol})$ were dissolved in buffer $[1 \mathrm{~mL}$, phosphate buffer $(10 \mathrm{~mm}), \mathrm{NaCl}(140 \mathrm{~mm})$, EDTA $(1 \mathrm{~mm}), \mathrm{pH} 6.6]$. The UV absorption at $260 \mathrm{~nm}$ was monitored as a function of temperature. The temperature was increased at a rate of $0.5^{\circ} \mathrm{Cmin}^{-1}$ over the range $5-80^{\circ} \mathrm{C}$. 


\begin{tabular}{|c|c|c|}
\hline Oligonucleotide & $m / z$ calcd & $m / z$ found \\
\hline 18 a (MALDI-TOF) & 3566.4 & 3566.2 \\
\hline $18 \mathrm{~b}$ (MALDI-TOF) & 3657.4 & 3656.0 \\
\hline $18 \mathrm{c}$ (MALDI-TOF) & 3700.4 & 3699.1 \\
\hline $18 \mathrm{~d}$ (MALDI-TOF) & 3687.5 & 3688.1 \\
\hline 18e (MALDI-TOF) & 3730.4 & 3729.1 \\
\hline $18 \mathrm{f}$ (MALDI-TOF) & 3686.5 & 3685.0 \\
\hline $18 \mathrm{~g}$ (MALDI-TOF) & 3729.5 & 3729.0 \\
\hline $18 \mathrm{~h}$ (MALDI-TOF) & 3733.5 & 3735.0 \\
\hline $18 \mathbf{i}$ (MALDI-TOF) & 3776.4 & 3777.1 \\
\hline 19a (HPLC-ESI) & 3644.5 & $1214.8 .(-3)$ \\
\hline 19b (HPLC-ESI) & 3735.5 & $1245.2(-3)$ \\
\hline 19c (HPLC-ESI) & 3778.5 & $1259.5(-3)$ \\
\hline 19d (HPLC-ESI) & 3765.5 & $1255.2(-3)$ \\
\hline 19e (HPLC-ESI) & 3808.5 & $1269.5(-3)$ \\
\hline $19 \mathrm{f}$ (HPLC-ESI) & 3811.5 & $1270.6(-3)$ \\
\hline $19 \mathrm{~g}$ (HPLC-ESI) & 3854.5 & $1284.8(-3)$ \\
\hline $19 \mathrm{~h}$ (HPLC-ESI) & 3735.5 & $1244.2(-3)$ \\
\hline 19i (HPLC-ESI) & 3778.5 & $1257.5(-3)$ \\
\hline 19j (HPLC-ESI) & 3765.5 & $1255.9(-3)$ \\
\hline 19k (HPLC-ESI) & 3808.5 & $1268.2(-3)$ \\
\hline 191 (HPLC-ESI) & 3811.5 & $1270.6(-3)$ \\
\hline $19 \mathrm{~m}$ (HPLC-ESI) & 3854.5 & $1284.8(-3)$ \\
\hline 20a (HPLC-ESI) & 6095.0 & $2030.3(-3)$ \\
\hline $20 \mathrm{~b}$ (HPLC-ESI) & 6186.0 & $2061.0(-3)$ \\
\hline 20d (HPLC-ESI) & 6215.1 & $1552.7(-4)$ \\
\hline $20 f$ (HPLC-ESI) & 6216.1 & $2070.7(-3)$ \\
\hline $20 \mathrm{~h}$ (HPLC-ESI) & 6262.1 & $2086.0(-3)$ \\
\hline $20 \mathrm{j}$ (HPLC-ESI) & 6274.1 & $2090.0(-3)$ \\
\hline
\end{tabular}

Circular dichroism measurements: $C D$ measurements were carried out at $25^{\circ} \mathrm{C}$ with the same solution as used for the $T_{\mathrm{m}}$ studies. Samples were scanned from 320 to $220 \mathrm{~nm}$ at $0.5 \mathrm{~nm}$ intervals averaged over $1 \mathrm{~s}$.

EcoRI restriction assay: The oligonucleotide $(0.4 \mathrm{OD})$ was dissolved in DTT buffer [100 $\mu \mathrm{L}, \mathrm{pH} 7.5, \mathrm{MgCl}_{2}(190.4 \mathrm{mg}), \mathrm{NaCl}$ $(1.17 \mathrm{~g})$, Tris $(1.21 \mathrm{~g}), \mathrm{DTT}(15.4 \mathrm{mg})$ in water $(200 \mathrm{~mL})]$. The solution was heated at $70^{\circ} \mathrm{C}$ for $2 \mathrm{~min}$ and then cooled in an ice-bath. After the addition of EcoRI ( 270 units), the solution was incubated at $23^{\circ} \mathrm{C}$. Aliquots $(20 \mu \mathrm{L})$ were taken and analysed by HPLC with use of triethylammonium acetate buffer $(\mathrm{pH} 8.0)$ containing $5 \%$ acetonitrile (solvent 1 ) and acetonitrile (solvent 2 ) on a C-18 reversed-phase column with UV detection. The solvent gradient was as follows: initially $99 \%$ solvent 1 , then a 20 min linear gradient to $25 \%$ solvent 2,5 min with $100 \%$ solvent 2,5 min with $100 \%$ solvent 1.

Primer-extension reactions: The recombinant enzymes were purified as described in the literature. Pfu DNA polymerase: see ref. [26]. Human DNA polymerase $\beta$ : see ref. [27]. Dpo4 DNA polymerase: adapted from ref. [28]. The reaction mixtures $(10 \mu \mathrm{L})$ contained ${ }^{32}$ P-labelled primer F15 (5'-CGCGTC GTAGAT GCT-3', $100 \mathrm{nM})$, the different templates $(150 \mathrm{nM})$ and dNTPs $(100 \mu \mathrm{M})$ in $1 \times$ reaction buffer [for $\mathrm{Pfu}$ DNA polymerase: Tris. $\mathrm{HCl}(\mathrm{pH} 8.8$, $20 \mathrm{~mm}),\left(\mathrm{NH}_{4}\right)_{2} \mathrm{SO}_{4}(10 \mathrm{~mm}), \mathrm{KCl}(10 \mathrm{~mm}), \mathrm{MgSO}_{4}(2 \mathrm{~mm})$, Triton X$100(0.1 \%, v / v)$, BSA $(0.2 \%, w / v)$; for human DNA polymerase $\beta$ : Tris. $\mathrm{HCl}(\mathrm{pH}$ 8.0, $50 \mathrm{~mm}), \mathrm{MgCl}_{2}$ (10 mM), DTT (2 mm), $\mathrm{NaCl}(20 \mathrm{~mm})$, $\mathrm{KCl}(20 \mathrm{~mm})$, glycerol $(1 \%, \mathrm{v} / \mathrm{v})$; for Dpo4 DNA polymerase: Tris. $\mathrm{HCl}$ $(\mathrm{pH} 7.8,50 \mathrm{~mm}), \mathrm{DTT}(5 \mathrm{~mm}), \mathrm{NaCl}(50 \mathrm{~mm}), \mathrm{MgCl}_{2}(5 \mathrm{~mm})$, glycerol $(5 \%, v / v)]$. The final enzyme concentrations in the reaction mixtures were $10 \mathrm{~nm}$ for Pfu DNA polymerase, $200 \mathrm{~nm}$ for human DNA polymerase $\beta$ and $50 \mathrm{~nm}$ for Dpo4 DNA polymerase. The template sequences used are depicted in Figure 6. F15 was labelled by use of $\left[\gamma^{32} \mathrm{P}\right]$-ATP by standard techniques. Annealing of the primer to the template strand was conducted in Tris. $\mathrm{HCl}(\mathrm{pH} 7.5,20 \mathrm{~mm})$ and $\mathrm{NaCl}(50 \mathrm{~mm})$ from $95^{\circ} \mathrm{C}$ to $25^{\circ} \mathrm{C}$ over at least $1 \mathrm{~h}$. Mixtures were incubated for $30 \mathrm{~min}$ at different temperatures $\left(68^{\circ} \mathrm{C}\right.$ for Pfu DNA polymerase, $37^{\circ} \mathrm{C}$ for human DNA polymerase $B$ and for Dpo4 DNA polymerase) and the reactions were stopped by the addition of stop solution [ $45 \mu \mathrm{L}$, formamide $(80 \%, v / v)$, EDTA $(20 \mathrm{~mm})$, bromophenol blue $(0.025 \%, w / v)$, xylene cyanol $(0.025 \%, w / v)]$. The mixtures were separated by denaturating PAGE $(12 \%)$ followed by visualisation through phosphorimaging.

\section{Acknowledgements}

C.M. and A.M. are grateful for financial support from the Deutsche Forschungsgemeinschaft (ME 1161/9-1 and MA 2288/8-1) and the University of Hamburg.

Keywords: aromatic amines - chemical carcinogenesis - DNA adducts . DNA damage $\cdot$ electrophilic amination

[1] R. C. Garner, Mutat. Res. 1998, 402, 67-75.

[2] F. A. Beland, F. F. Kadlubar, Environ. Health Perspect. 1985, 62, 19-30.

[3] F. P. Guengerich, Drug Metab. Rev. 2002, 34, 607-640.

[4] R. J. Turesky, S. C. Rossi, D. H. Welti, J. O. Lay, F. F. Kadlubar, Chem. Res. Toxicol. 1994, 7, 752-761.

[5] F. Marroquin, N. Coyote, Chem.-Biol. Interact. 1970, 2, $151-153$

[6] R. Saffhill, P. J. Abbott, Chem.-Biol. Interact. 1983, 44, 95-110.

[7] Y. Zhou, L. J. Romano, Biochemistry 1993, 32, 14043-14052.

[8] Y. Zhou, S. Chladek, L. J. Romano, J. Org. Chem. 1994, 59, 556-563.

[9] L. C. J. Gillet, O. D. Schärer, Org. Lett. 2002, 4, 4205-4208.

[10] L. C. J. Gillet, J. Alzeer, O. D. Schärer, Nucleic Acids Res. 2005, 33, 1961 1969.

[11] B. P. Cho, F. A. Beland, M. M. Marques, Biochemistry 1992, 31, $9587-$ 9602.

[12] B. P. Cho, F. A. Beland, M. M. Marques, Biochemistry 1994, 33, 13731384.

[13] G. R. Hoffmann, R. P. P. Fuchs, Chem. Res. Toxicol. 1997, 10, 347-359.

[14] M. I. Jacobsen, C. Meier, Synlett 2006, 2411-2414.

[15] N. Böge, S. Krüger, M. Schröder, C. Meier, Synthesis 2007, 3907.

[16] N. Böge, M. I. Jacobsen, Z. Szombati, S. Baerns, F. Di Pasquale, A. Marx, C. Meier, Chem. Eur. J. 2008, 14, 11194-11208.

[17] R. G. Eason, D. M. Burkhardt, S. J. Phillips, D. P. Smith, S. S. David, Nucleic Acids Res. 1996, 24, 890-897.

[18] F. E. Evans, D. W. Miller, F. A. Beland, Carcinogenesis 1980, 1, 955-959.

[19] F. Johnson, C. Y. Huang, P. L. Yu, Environ. Health Perspect. 1994, 102, $143-149$.

[20] S. Shibutani, R. Gentles, F. Johnson, A. P. Grollmann, Carcinogenesis 1991, 12, 813-818.

[21] D. Dwyer-Halliquist, K. Kezdy, S. Agarwal, Biochemistry 1982, 21, 4693 4697.

[22] F. P. Guengerich, Chem. Rev. 2006, 106, 420-452.

[23] W. A. Beard, S. H. Wilson, Chem. Rev. 2006, 106, 361-382.

[24] a) F. Boudsocq, S. Iwai, F. Hanaoka, R. Woodgate, Nucleic Acids Res. 2001, 29, 4607-4616; b) H. Ling, F. Boudsocq, R. Woodgate, W. Yang, Cell. 2001, 107, 91-102; c) R. L. Eoff, A. Irimia, M. Egli, F. P. Guengerich, J. Biol. Chem. 2007, 282, 1456-1467; d) R. L. Eoff, K. C. Angel, M. Egli, F. P. Guengerich, J. Biol. Chem. 2007, 282, 13573-13584.

[25] J. Cline, J.C. Braman, H. H. Hogrefe, Nucleic Acids Res. 1996, 24, $3546-$ 3551.

[26] N. Z. Rudinger, R. Kranaster, A. Marx, Chem. Biol. 2007, 14, 185-194.

[27] S. Gieseking, K. Bergen, F. di Pasquale, W. Welte, K. Diederichs, A. Marx, J. Biol. Chem. 2011, 286, $4011-4020$.

[28] K. A. Fiala, Z. Suo, Biochemistry 2004, 43, 2116-2125. 